\title{
Forest Rehabilitation in Afghanistan
}

- Q 90.3 Q $r=-\infty y$

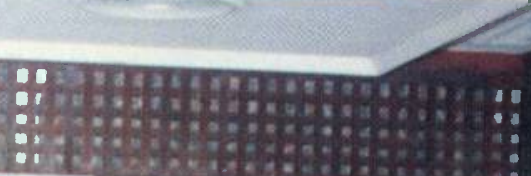

(8)

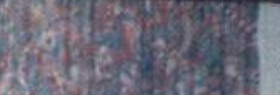




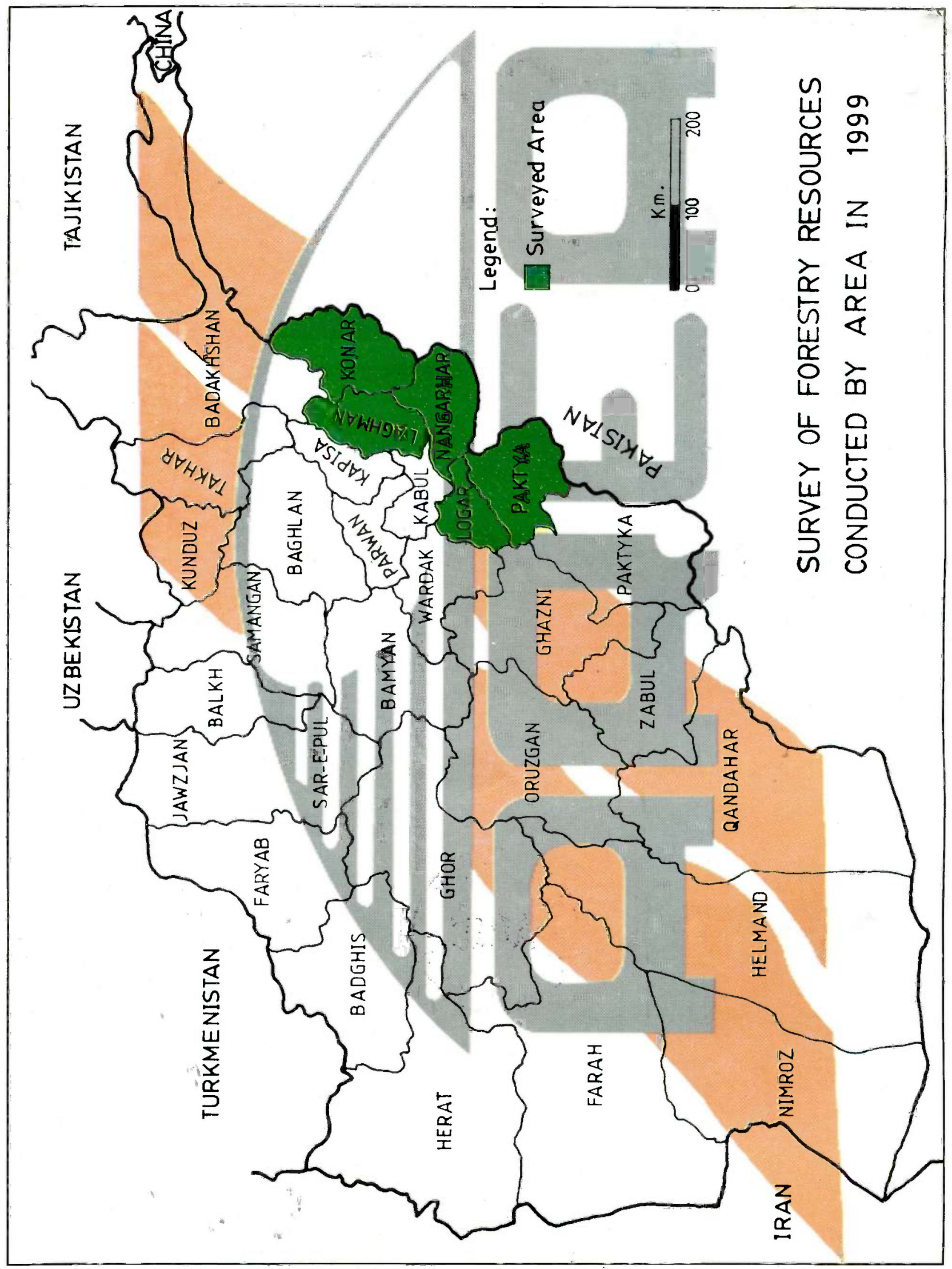




\section{Forest Rehabilitation in Afohanistan}

ZOPP Workshop Report $28^{\text {th }}-31^{\text {st }}$ July, 1999
Peshawar

Moderation \& Report by Mahmood Hemani

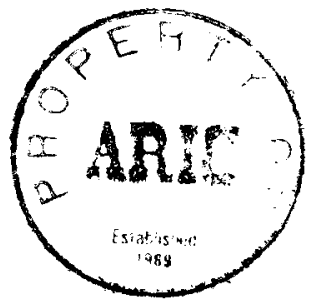

Organised by:

Agency for Rehabilitation \& Energy-conservation in Afghanistan (AREA) 


\section{Table of Content}

1. List of Abbreviations

Page \#

2. Acknowledgement 3

3. Background 4

4. Introduction $\quad 6$

5. Workshop Inauguration $\quad 7$

6. Presentation of Baseline Survey of Forest Resources of Afghanistan 8

6. Introduction to Workshop Programme, Methodology \& Participants 8

7. Problem Analysis 9

8. Objective Analysis 10

9. Alternative (Strategy) Analysis 11

10. Participation (Stakeholder) Analysis $\quad 12$

10. Project Planning Matrix (PPM) - Logical Framework Matrix - 13

11. PPM - Overall Goal, Project Purpose \& Results 13

12. PPM - Important Assumptions 14

13. PPM - Objectively Verifiable Indicators and Means of Verification 15

14. PPM - Major Activities 16

16. Workshop Evaluation and Adjournment 16

\section{Annexes}

\#1 Complete list of workshop participants

\#2 Opening Speech by: Mula Khawaja Abdul Basir,

Ministry of Agriculture and Livestock, Afghanistan.

\#3 Presentations: Findings of the Baseline Survey

Part A: Present Status of Southeast Forests of Afghanistan.

Part B: Use of Digital Land Cover Database in the Survey.

\#4 Chart: Introduction of Participants and their Expectations

\#5 Chart: Problem Tree

\#6 Chart: Objective Tree + Alternative Analysis

\#7 Chart: Participation (Stakeholder) Analysis

\#8 Chart: Logical Framework Matrix - LFM / PPM

\#9 Chart: Workshop Evaluation

\#10 Closing Statement by: Maulawy Abdul Tawab Qazi Zada, Ministry of Planning, Afghanistan

\#11 TORs: Baseline Survey

\#12 TORs: Planning Workshop 
ACBAR Agency Coordinating Body for Afghanistan Relief

ADA Afghan Development Association

$\mathrm{AGCHO}$ Afghan Geodesy and Cartography Head Office

AREA Agency for Rehabilitation \& Energy-conservation in Afghanistan

$\mathrm{BBC}$ British Broadcasting Corporation

CCA Cooperation Center for Afghanistan

EC

European Commission

EU

European Union

FAO

Food and Agriculture Organisation

FECT

Fuel Efficient Cooking Technology

GO

Government Organisations (departments)

HRD

Human Resource Development

IEA

Islamic Emirate of Afghanistan

IUCNP

International Union for Conservation of Natural Resource Pakistan

LFA

Logical Framework Analysis

LFM

Logical Framework Matrix

$\mathrm{M}+\mathrm{E}$

Monitoring and Evaluation

MADERA Mission D'aide Au Development Des Economies Rurales En Afghanistan

MOV

Means of Verification

NGO

Non-governmental Organisation

NOVIB

Netherlands Organization for International Development Cooperation

NPO/RRAA

Norwegian Project Office/Rural Rehabilitation Association for Afghanistan

NR

Natural Resource(s)

NRM

Natural Resource Management

OVI

Objectively Verifiable Indicators

PPM

Project Planning Matrix

PRA

Participatory Rural Appraisal

QQTL

Quantity, Quality, Time and Location

TORs

Terms of Reference

UN

United Nations

UNDP

United Nations Development Programme

UNEP

United Nations Environment Programme

UNHCR

United Nations High Commission for Refugees

VOA

Voice of America

ZOPP

Ziel Orientierte Projekt Plannung (Objectives Oriented Project Planning). 
All in all, the workshop appears to have been successful. Most importantly, participants appeared satisfied with the strategy designed as depicted in the Project Planning Matrix (PPM), and from feedback offered during and after the workshop. The participatory dynamics and level of personal satisfaction expressed by individual participants appeared quite high.

In conclusion, it remains only for the undersigned to thank all the workshop participants, for their active and valuable contributions and the co-operation that made the workshop a success.

Thanks are also due to Mr. Rafaat Ludin for clear and comprehensive briefing, as well to Mr. Mathew Owen for continued support throughout the workshop proceedings.

Of course, not to forget Mr. Sultan Maqsood Fazil and his team for dedicated, energetic and cheerful assistance and for taking good care of the participants' needs.

\author{
Mahmood Hemani \\ ViCAR Consulting, Karachi
}


To date, no specific environmental study has been carried out in Afghanistan. The lack of information on the quality of air, water, vesetation. land, and other environmental factors could be attributed to the nonexistence of agencies at state level or very few non-governmental organisations ( $\mathrm{MOS}$ ) devoted to this issue. Studies revealed that until at least 2000 B.C.E, the land of Afghanistan was covered with cedarrich forests, and had a different pattern of climatic and life support system than that of today

The ecosystem in Afghanistan had never been damaged to the extent that it has been in the last two decades. This deterioration has been created by the unlimited use of nature and its energy. Albeit, this envirommental degradation was and is being enhanced by war

Mountainous terrains with little or no vegetation, typical of an arid country, occupy two thirds of the landscape of Afghanistan. For this reason, the vegetation in these terrains plays a vital role in the ecosystem. For example, consider the role of pistachio (Pistacia vera, yielding) among hundreds of other floras, it is found out that it not only provides climatic and environmental stabilisation over the areas of its growth, but eases the life of thousands of families by providing them with a natural source of income
Half of the remaining parts of the country's landscape are deserts, which are hostile enviromments. The rest are farmlands and pastures. At present, only six percent of the fifteen percent of agricultural land in Afghanistan is under cultivation. In the past twenty years, the agricultural areas have been drastically decreased. It is estimated that thirty percent of farmlands and pastures have been lost either by abandonment or degradation. The farmlands in the province of Kabul have been lost due to degradation resulting from the expansion of the urban institutions. This led to a drastic change of the previously dominant climatic and environmental factors in this region. Compared to that of 1979, agricultural farm products have decreased fifty percent. To compensate for this loss, rural people started to utilise the free natural resources of their environment The end result of this process was a disaster for few natural forests, which were cut and smuggled to neighbouring countries.

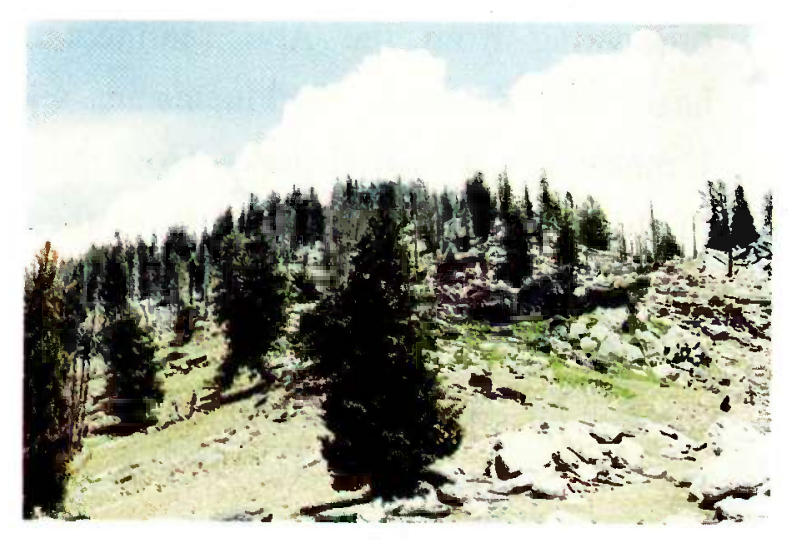


Deforestation, floods and avalanches added to the devastation. Once the forest's productivity was declined or monopolised by certain warlords, the poor farmers sought another cheap and accessible alternative, which was the cultivation of opium. Afghan warlords and the growing international drug market then, encouraged this. Hence, this resulted in further degradation of Afghanistan's environment.

Many forested areas and farmlands were burned and degraded by the use of heavy war technology and chemicals as well as due to disputes of ownership. It is estimated that ten thousand villages and their surrounding environments were destroyed. This continuous process still takes its toll on the environment. Even though Afghanistan itself doesn't have any industry to create pollutants, smog is a common phenomenon in most of the urban areas.

Trans-boundary air pollution is another concern. Due to this, Afghanistan receives enormous amounts of pollutants originating from the Aral sedimentary basin and the Iran, Turkmenistan, and Uzbekistan's. industrial parks. How much of the pesticides originating from these countries and world-wide end up on Afghanistan's lands and environment through air currents and rains, is another mystery that is adding to the environmental crisess.
Chemical weapons have been used during the Afghan war with the Soviets, and this caused severe shortterm damage to the environment and ecosystem

No data exists on their long-term effects.

It could be concluded that at present, the environment in Afghanistan is in deep crises.

The problems not only affect the people of Afghanistan and their ecosystem, but the whole world.

Once any of the environmental components are lost, recovery is almost impossible, e.g., the capture of a pair of Caspian Tigers (Panthera Tigris Virgata), roaming in the mountains of eastern Afghanistan in April 1997, may have put an end to the survival of this highly endangered and almost extinct species.

The people of Afghanistan are in desperate need of help to repair their natural habitat and ecosystem.

The international community is responsible for lending Afghans a hand in order to help revive this wounded piece of our common home, earth. 
The AREA operates in three regions inside Afghanistan - Kabul, Jalalabad and Herat besides having its base in Peshawar, Pakistan.

The AREA has been in operation for five years; much of this time has been devoted to planning and implementation of its programmes keeping in line with the objective of its creation, i.e., "to contribute towards rehabilitation and development of Afghanistan in an environmentally sound manner". Contrary to the expectations, keeping in view the circumstances existing within Afghanistan, the AREA has succeeded in gaining ground and has now embarked on expanding the scope of work to more macro level aspects of environment conservation.

Keeping up with the widened scope, AREA executed a study on the Forest resources of Afghanistan and invited stakeholders from Afghan Government, NGOs, academia and UN bodies to a planning workshop to discuss and elaborate an overall logical framework plan for the rehabilitation of forest in Afghanistan. A complete list of workshop participants is presented in Annex \#1.

This report covers the proceedings and the results of the four-day workshop held at Pearl Continental Hotel, Peshawar from $28^{\text {th }}$ through $31^{\text {st }}$ July 1999.

The planning methodology used in the workshop is based on ZOPP. ZOPP is the acronym for the German term "Ziel Orientierte Projekt Plannung" (Objectives Oriented Project Planning). ZOPP is a participatory planning methodology that uses a sequence of successive steps leading to a project planning matrix (logical frame matrix - LFM) which illustrates the basic structure of the overall project.

The workshop succeeded in achieving the objective of preparing an overall project-planning matrix (PPM) - logical frame matrix (LFM). Above all a common understanding on aims and objectives for the forest conservation in Afghanistan was reached in the workshop. However, due to time constraints the stakeholders' analysis was carried out to minimum possible level by the workshop.

The end product, a logical framework matrix - LFM prepared by the workshop participants (appendix \#7) contains all the required information for the development of more elaborate work plans. Either for joint implementation by the stakeholders or for inclusion of some/all of the objectives in the work plans of the respective GO/NGOs taking into account the past experience and demographic characteristics. 
The workshop started with the recitation of few verses from the Holy Quran

Proceedings began with welcome remarks bs $\mathrm{Mr}$ Rafat Ludin. Managing Director of AREA. He welcomed the participants and wished the participants successful time and work shop

Communicating the distinction about the event he mentioned that the workshop is being organised by the AREA but it is not for AREA The workshop is organised solely for the purpose of

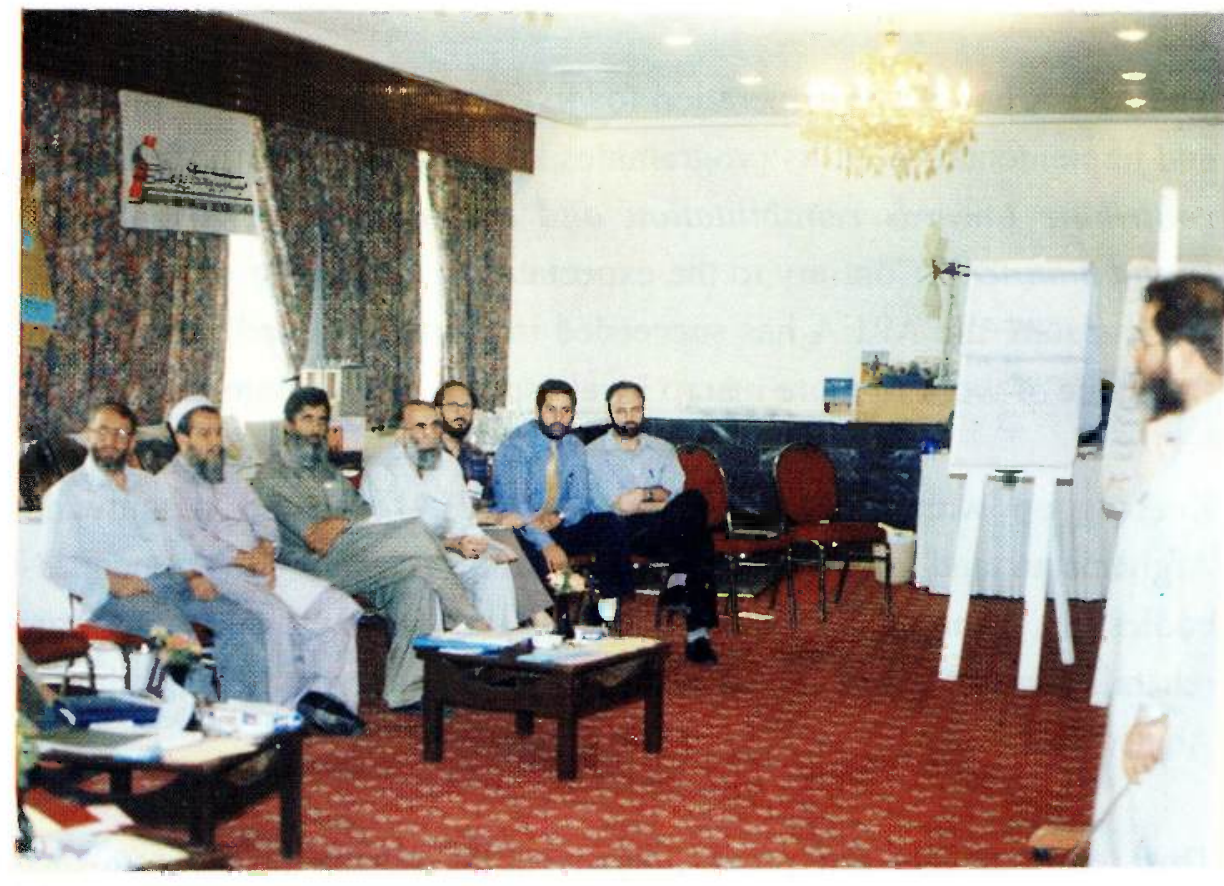
generating interest of the stakeholders in the forestry / environmental issues of Afghanistan

The workshop is a step towards initiating the process of tackling the envirommental problems in Afghanistan, thus, it is being organised for Afghanistan and its success will contribute to the rehabilitation of Afghanistan. The results can be used by AREA as well as by the Aidcommunity and the Govermment

He hoped that the group will have fruitful discussion on issues relating to forest conservation and would help develop a common vision for the rehabilitation/conservation

He also mentioned that the workshop should have been held much earlier but it is never too late to take the right steps

Mula Khawaja Abdul Basir, Representative of Ministry of Agriculture and Livestock, IEA speaking on behalf of the Government of Afghanistan expressed good wishes to the workshop participants and success in rehabilitation and energy conservation in Afghanistan

Highlighting the importance of such workshops, he mentioned that Ministry of Agriculture values such events and all such efforts by NGOs and hoped that the plans would result into practical steps. 
- Mula Basir also gave detailed presentation of Afghanistan's demography population, literacy and forest cover and its rapid reduction as well as its importance and affects on overall climatic conditions.

Admitting the absence of reliable data on forest resources, he mentioned that it is estimated that in the last two decades Afghanistan has lost more than a quarter of 500 hectares of forest cover mostly in the eastern zone. This wood mostly utilised for industrial purposes was smuggled to other countries. Whatever is remaining, is being cut indiscriminately particularly in Nuristan and Kunar provinces

$\mathrm{He}$ also suggested that steps for the protection of existing forest cover as well as for man-made plantation should be taken side by side to introduction of alternative fuel sources to reduce the pressure on limited forest resources.

In the end, he suggested that following should be considered by the workshop participants for inclusion in the strategy to be developed in the workshop:

- Kabul greenbelt with the view to watershed management,

- Rehabilitation and reconstruction of Qargha reservoir to revive the forests on the hills and areas surrounding it,

- Rehabilitation of Paghman hill forests,

- Protection and conservation of industrial woods of eastern zone and closed forests of northern areas being cut irrationally.

Script of Mula Khawaja Abdul Basir's opening speech is presented in Annex $\# 2$.

\section{Presentation of Baseline Survey of Forest Resources of Afghanistan}

The two member survey team comprised of Prof. G. N. Nassery and Mr. Mohammad Shuaib Partaw jointly presented the findings of their strenuous survey. The survey was conducted over a period of two months utilising the digital maps, satellite images and land cover maps obtained from various sources, like, FAO, UNDP, ACBAR, ProMIS, etc. It also required extensive travel mostly on foot to physically verify the data. The presentation was divided into two parts; Mr. Partaw, the only Afghan Remote Sensing Expert, gave an insight into the use of digital land cover database of Afghanistan in the survey. His presentation included various types of coverage (Class) of forests. See Annex \#3 - Part B. Prof. Nassery's presentation summarily conferred the present status of the Southeast forests of Afghanistan. The focus of the presentation was on:

- Types of forests,

- Usage and users,

- Consequences of deforestation,

- Natural regeneration,

Concluding the presentation Prof. Nassery apprised the workshop participants that if the present rate of deforestation continues by the year 2014 there will be no forest left in any part of the Afghanistan. The presentation also gave details for various areas covered under the survey. Their findings included information concerning coverage figures from 1971 compared with 1999, percentage of reduction, major types, major causes of deforestation, rate of deforestation and the approximate time by when zero forest status is likely to occur. The presentation revealed that zero forest status will first occur in Paktia by the year 2003 whereas the last of forests cover will be lost in Laghman by 2014. The replica of Prof Nassery's presentation is in Annex \#3 - Part A. 


\section{intreatudion to Workshop Programme, Methodology and}

\section{Participants}

After the inaugural session, the workshop participants agreed upon the workshop agenda and timings.

The moderator introduced the participants to the philosophy and rationale of the ZOPP method, then went on to describe the techniques of problem and objectives analysis.

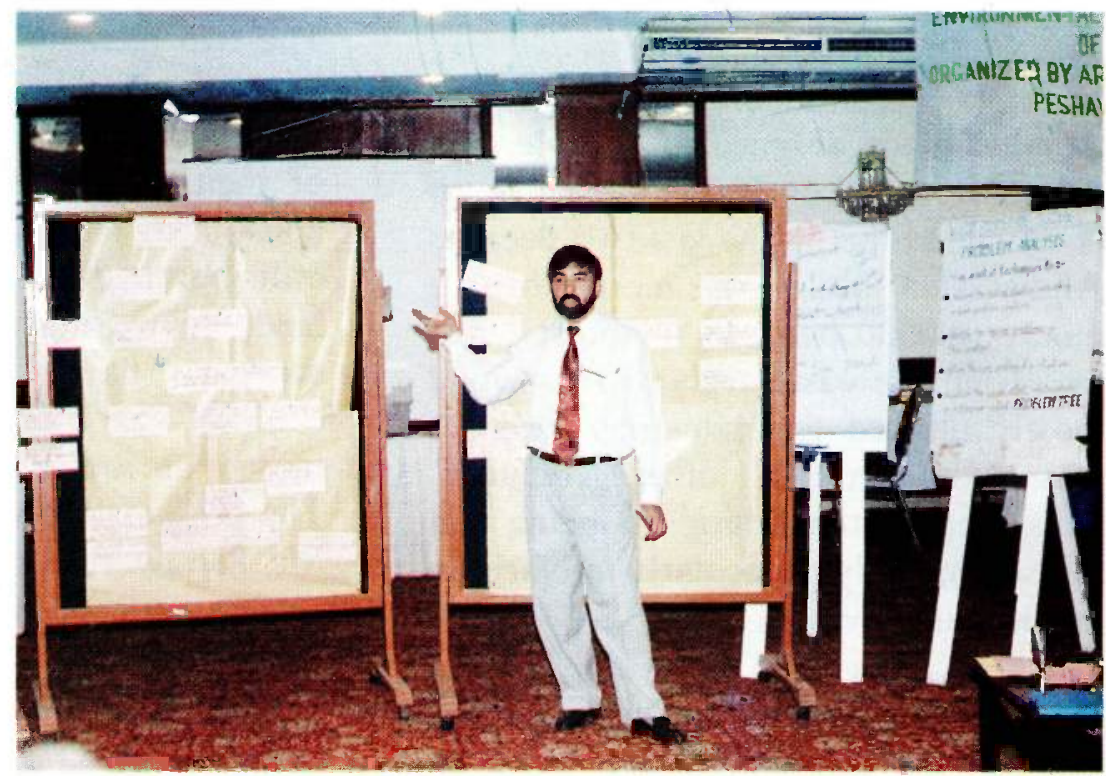

The design of the logical framework matrix (LFM) - project planning matrix (PPM) were explained in brief. In addition to this introduction, before the start of each step detailed understanding into how to do the analysis were also given. The participants were also introduced to the card-and-chart technique used extensively in the workshop.

Later, each participant introduced himself and gave their expectations from the workshop on cards.

Most of the expectations pertained to development of a strategy to arrest the process of deforestation, outlining the practical solutions for rehabilitation of forests resources as well as look into the overall environmental aspects, etc.

An overview of the presentation of the participant's expectations can be found in appendix \# 4. 
The working session of the workshop began with the problem analysis. The purpose of the problem analysis is to

Idenify and analyse the major problems smroming the given condition. Arrive at a group consensus about the core problem, which describes the cenral point of the overall problematic condition, and visualise the cause-effect relationships in a Problem Tree.

Participants were asked to write on a card, the single problem they believed to be most central to the issue of deforestation. The cards with corresponding issues were clustered to highlight the issues which majority of the participants thought to be the major problem. The next step was to identify a core-problem of the situation. There were different suggestions given by the participants from amongst the problems submitted earlier. Some of the participants insisted on "poverty" and "continued fighting" as the core problems. This led to an explanation about difference in root problem, coreproblem, causes and effects. Finally the group agreed on following core problem:

\section{"FOREST RESOURCES OF AFGHANISTAN ARE RAPIDLY SINKING"}

After reaching an agreement on the coreproblem, the rest of the problems identified by the participants were placed as either causes or effects. Later, the group was given the opportunity to submit additional problems that have not been covered so far. A very large number of problems were presented. Almost all the problems submitted were causes to the core-problèm; . these were then clustered and arranged in causeeffect relationship under direct causes of the coreproblem. Following problems emerged as major (direct) causes of the core-problem:

- High market demand for timber

- Inadequate state management of forests

- Indiscriminate felling of trees

- Encroachment on forest land for agricultural use

- Inefficient use of timber

- Inadequate initiative to create man-made forests

- Natural regeneration is not always enabled

- Export of timber to foreign countries

- Family/tribal feuds leading to destruction of forests

The effect part of the tree was then developed in the plenary. The participants were asked to write cards describing the effects of the core problem, these were then arranged in logical hierarchy in order have a general overview of the consequences of rapid deforestation. The analysis resulted in following direct effects of the core-problem:

- Water run off

- Evaporation accelerated

- Destruction of vegetational cover

- Reduction in rain fall

- Air pollution is increased

- Negative effects on indigenous medicine plants

- Loss of habitat of animals and humans

These together with their effects, like, reduction in food supplies, desertification, scarcity of water, etc. ultimately result in negative effects on national economy as well as the overall environment. The group spent considerable time in analysing the problems. The problem analysis turned out to be unusually difficult since the cause-effect relationships between problems were not always direct or indeed immediately apparent. Viciousness of the situation also caused difficulty during the analysis. The final product of the analysis, Problem Tree, gives an elaborate overview of the problematic situation existing in Afghanistan. The tree is presented in Annex \#5. 


\section{OBJECTIVE ANALYSIS}

After the problem analysis that portrays the negative existing situation, an objective analysis was carried out. The purpose of the analysis is:

All the problem stakments in the Problem Irece are transformed into positive statement descrhing the fillure situation that will be achieved by solving the frestems.
During the analysis following additional objectives - for which no problems were identified, were added.

- Consumers are more aware of the value of wood

- More trees are planted (with crops) on private farms

- Human sanitation condition significantly improved

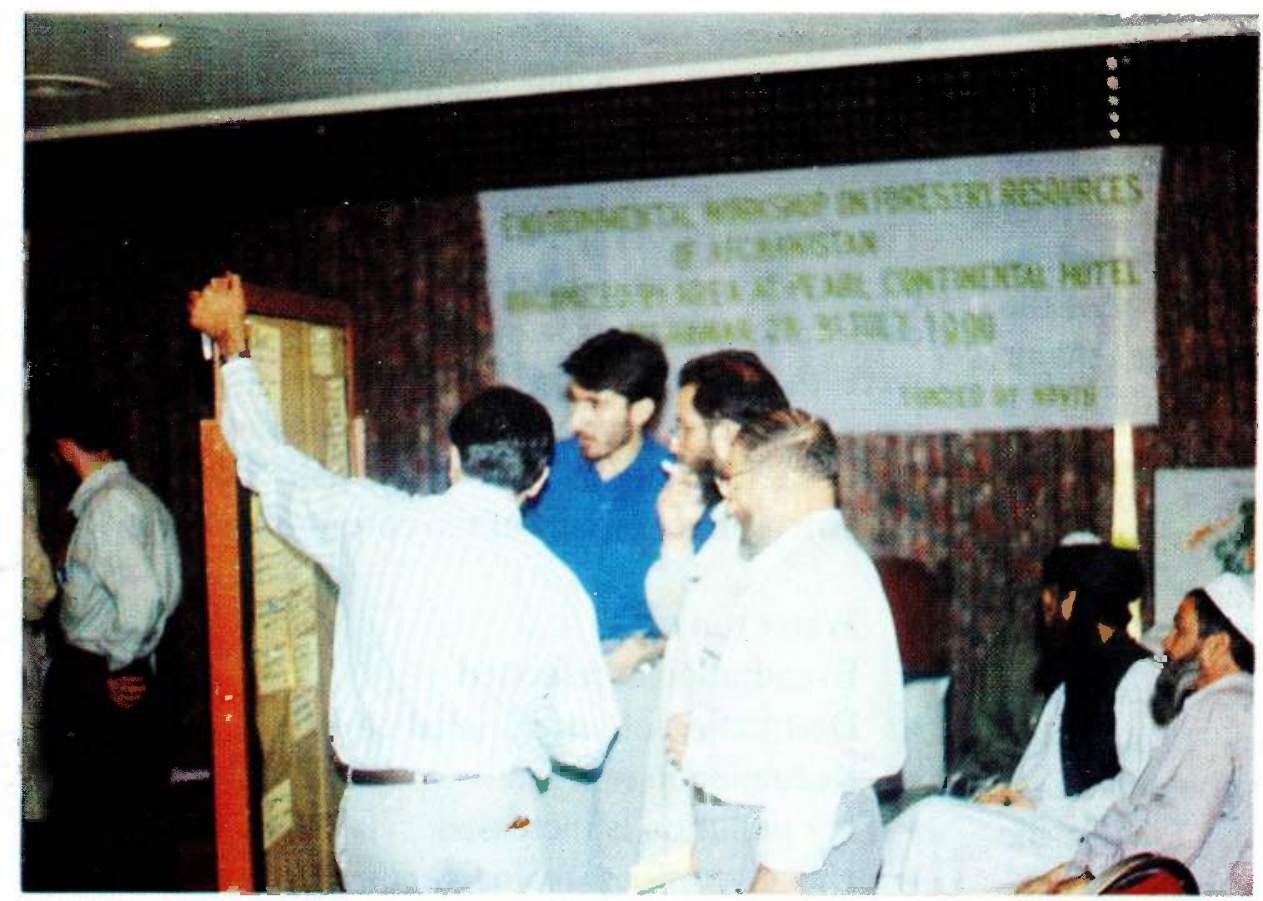

The group at length deliberated on the objectives for the problem pertaining to 'high : population growth"

Some participants, especially from Afghanistan, showed their strong opposition to the suggested objective of "family planning promoted".
The process adopted for the formulation of the objectives was that the plenary was divided into four sub-groups to work out the objective statement for each problem card. The guiding principles for formulation of objectives were to assess the statement for a) what is desirable, and, b) is it realistically achievable.

The group work was later shared with the plenary. The plenary finally reached consensus on the objective of "population growth is controlled' to be rephased. "The means-end relationship within the various branches were also reviewed.
They mentioned that if any such objective is included in the strategy the community or Government might not provide the required support.

The Objective Tree constructed by the participants is presented in Annex \#6. 


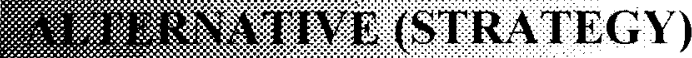

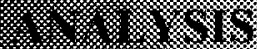

In the step of Alternative Analysis the workshop participants discussed which of the objectives from the Objectives Tree would form part of the strategy. The purpose of the analysis is to.

Assess, using specific criteria, which of the objectives are desirable alternative solutions for the strategy.

The criteria developed by the group for the selection of objectives were

- Environmental impact

- Time frame of 5 years - possibility of making substantial intervention towards the objective within time frame.

- Social viability

- Economic feasibility

Due to peculiar nature of the situation in Afghanistan and the unclear resource availability the workshop focused on development of a comprehensive but focused strategy for forest rehabilitation in Afghanistan. The workshop participants, in response to a question on which of the objectives, in their opinion, should not be included in the strategy mentioned that they would like to see all these objectives included in the strategy. This led to a discussion concerning taking charge of achieving the objectives in full or part or through facilitation. After realising the fact that no single organisation can achieve all the objectives in full, the group agreed to make selection of objectives for various levels/types of intervention. While browsing through the means part of the Objective Three, separate marks were placed for objectives: Symbol used on tree .

- Not to be pursued / included in the strategy ...................... //

- for which only facilitation would be provided and/or linkages would be developed
Rests of the objectives in the means part of the tree are to be actively pursued and included in the strategy. The workshop participants also included objectives that fall under the purview of the state with the view that the strategy developed should be comprehensive so that it reflects the role of all the stakeholders, where, state is part of it.

The group had lengthy discussions during the analysis; they discussed in detail the ways and means of achieving the objective under discussion. For instance, while discussing the objective of alternate income generating opportunities are available' the workshop participants expressed their reservation that it is not explicitly part of the "Forest Conservation/Rehabilitation" but there is need to recognise its necessity as it has come up in the analysis. It was also realised that if this objective is not achieved it will lead to the failure of the rest of the interventions/efforts. The group also pointed out that in the past many donor supported projects tried to improve the behaviour but were unsuccessful. However, this strategy would need to more seriously pursue this objective as it forms the basic cause of the present situation of rapid deforestation.

The participant arrived at following conclusion:

1. Objectives concerning dependence on forest resources for livelihood, poverty alleviation measures in place and alternate income generating opportunities available/created were selected for facilitation through linkages and networking

2. The objectives marked as outside the grasp of this "Programme" include political and security situation stabilised, employment opportunities are created, population growth is controlled, and efficient agriculture practices adopted and animal husbandry practices are improved.

The markings made during the Alternative Analysis can be seen on the Objective Tree presented in Annex \#6, where different symbols (see inset - Alternative Analysis) depict the degree and type of intervention to make 


\section{PARTICIPATION (STAKEHOLDER) ANALYSIS}

The next step made in the workshop was the participation analysis. The purpose of the analysis is

Analyse the expectations, apprehensions and potentials of anticipated partners (organisations, institutions, groups; etc.) in the programme project. The information generated in this analysis is incorporated into the formulation of the strategy.

Due to time constraints a basic analysis was carried out during the workshop. The analysis primarily focused on establishing a base - to be improved in future, if required. The analysis gathered information on key players, their expectations and potentials - that can be utilised by the "Forest Programme" to its advantage as well as "Forest Programme's" expectations. The plenary session identified following partners in the "Forest Programme":

- Government

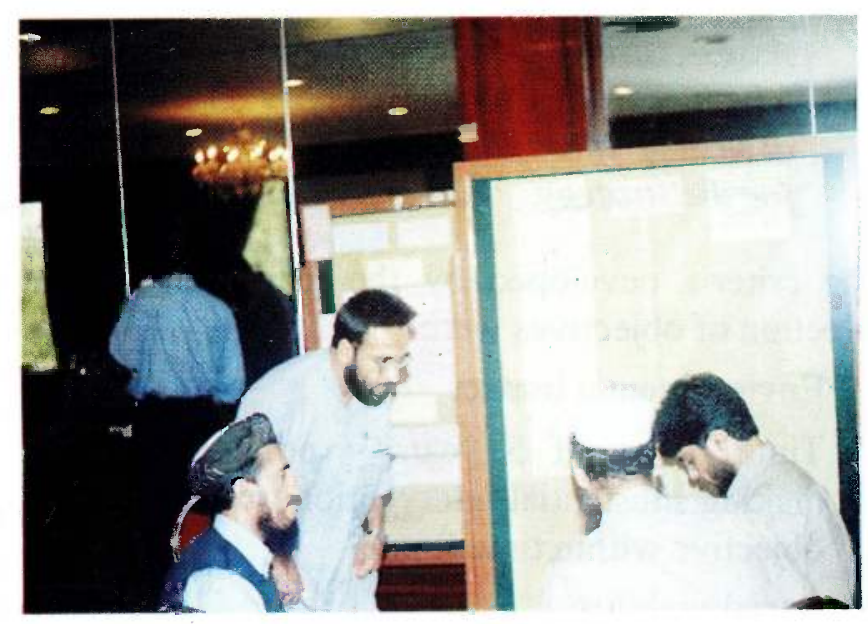

- Community + Local Councils

- UN Agencies + Donors + NGOs

- Influential and Religious Leaders

- Business Community - Traders, Transporters/Truckers, Wood based Industries

- Technical Institutions

- Training Institutions

- Day wagers involved in cutting of the trees

- Media-BBC, VOA, Radio Shariat, etc.

- Timber Smugglers*

* Timber smugglers was included in the analysis as a major opposing group but at the same time it is assumed that this group has the financial resources to switch to other businesses if the guidance and facilitation is provided. The approach adopted was that working groups were formed who studied partners mentioned above. Not all the sub-groups worked out the "Programme's" expectations from the partner. Later the results of the group work were presented and discussed in the plenary.

During the group work participants also included in the analysis negative potential as well as negative expectations for certain partners. These are reflected with negative sign in brackets "(-)" at the end of the statement, see Annex \#7.

It can be safely concluded that there are potentials, if exploited in correct manner, with targeted awareness programmes, enhancement of capacities and continued programme of introduction of alternate fuel sources and efficient technologies coupled with concentrated efforts for participatory reforestation/afforestation, can result in successful achievement of the objectives. See Annex \#7 for a complete overview.of the output of this brief analysis. 


\section{PROJECT PLANNING MATRIX (PPM) - LOGICAL FRAMEWORK MATRIX (LFM)}

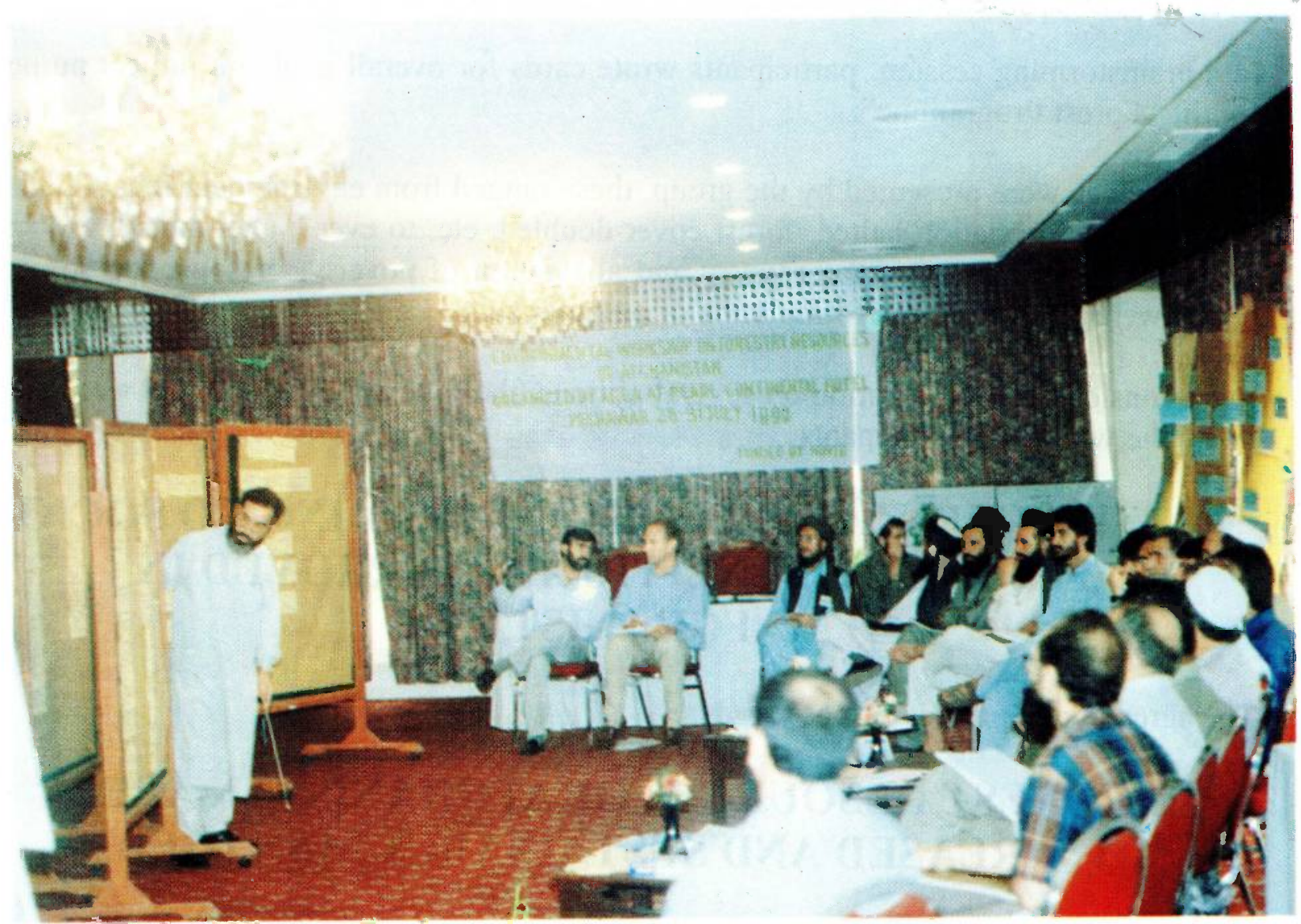

With the completion of Participation Analysis the workshop had collected enough information to proceed with the development of the project-planning matrix.

Project Panning Matrix (PPM) is a logical framework that provides a summary of the basic structure of the overall project programme.

The PPM indicates the direction of the project programme to which it contributes and it describes which outputs results in detail will be required to achieve the project purpose. In addition, it also illustrates what the standards for success are together with the information on certain external conditions that must exist in order for project to succeed in its ohjectives. 


\section{Overall Goal, Project Purpose and Outputs/Results}

In a brainstorming session, participants wrote cards for overall goal and project purpose for the "Forest Programme".

Several ideas were presented by the group, these ranged from environment rehabilitation, process of deforestation halted, forest cover doubled, etc. to ever higher aims like socioeconomic development of the country and alleviation of poverty, or some too specific, which were utilised for the formulation of output/results.

After considerable deliberation on several options, the following overall-goal was agreed on by the workshop participants.

\section{ENVIRONMENTAL CONDITIONS LEADING TO SOCIO- ECONOMIC BENEFITS ARE IMPROVED IN AFGHANISTAN}

The agreed upon project purpose reads:

\section{FOREST RESOURCES OF AFGHANISTAN ARE INCREASED AND SUSTAINABLY MANAGED}

This means that if the project purpose is achieved an important contribution will be made towards the above-mentioned overall goal.

In order to achieve the project purpose eight outputs/results were identified; these encompass the outcome of the alternative analysis. Participants identified major thrust areas from the objective tree as potential strategic components for the "Programme" to focus on, i.e.; all the objectives marked for inclusion in strategy are covered under one or the other result. A detailed reflection of the objectives covered under each output/result was made during activity formulation.

The output/results statements finalised by the plenary are:

1. Government and non-government structures for forest management are functioning.

2. Co-ordination: mechanisms for effective forestry management are strengthened/created among NGOs, private sector and government departments.

3. Comprehensive laws on forest management are in place.

4. People are aware of the importance and proper use of forests and are participating in forestry activities.

5. Laws on forest management are effectively enforced. 
6. The area covered by forest is significantly increased.

7. Consumption of wood from natural forests is reduced through more efficient use and switch to alternatives.

8. Diversification of income-generating opportunities is facilitated in forest-adjacent areas.

\section{Important Assumptions}

In order for the project to succeed, workshop participants were asked to take into account the assumptions.

Assumptions are those external factors that must exist in order for the programme to achieve its objectives.

Through brain storming in the plenary, participants reached consensus on the assumptions for the overall goal, project purpose and results. In total, twelve assumptions were added to the matrix.

The most important conditions for the success of the "Programme" as identified by the participants are:

- Political will exists to protect and better manage forest resources.

- Government resources for forest management.

- Donors support forestry activities.

In addition to above, certain result-specific assumptions were also identified. Crucial of them are:

- The government is willing to risk conflict with influential people (those involved in exploitation of forest resources for personal benefits only) and local communities.

- Economic incentives are in place to encourage switch to alternatives (for wood).

- Alternative income generating opportunities for communities around forests are provided/ available.

\section{Objective Verifiable Indicators (OVIs) and Sources/Means of Verification (MOVs)}

The purpose of formulating Objectively Verifiable Indicators is to decide on performance standards for measuring the success of the project objectives.

The process adapted for the identification of the indicators and means of verification was that the plenary was divided into three sub-groups to formulate indicators. Each of the groups was given up to three outputs/results to work on. The task given to the sub-groups was to first identify the key characteristics of the indicators and then specify the quantity, quality and time where applicable. Since the funding as well as the regions for implementation is not clear the indicators do not reflect the location aspect.

The indicators for the project purpose and overall goal were not formulated as the participants felt difficulty in comprehending the impact for such level of objectives. In their opinion, any impact generated will be of a very limited extend and difficult to be measured at the end of the five-year phase. It is very important that once the funding for this "Programme" is secured the implementers must review the indicators for QQTL (quantity, quality, timeline and location) keeping in mind the budgetary constraints as well as to keep-up with the inter-dependent objectives/activities. The matrix, presented in Annex \#8, contains all the indicators identified during the workshop for the eight results 
It would be highly appropriate for the "Forest Programme" to devise mechanism for the realisation of these assumption. Other assumptions enumerated for the output/results are about the willingness of the stakeholders to be co-ordinated, revised forest laws passed by the government, people willingly participate in conservation activities and private sector is willing to invest in favour of diversification.

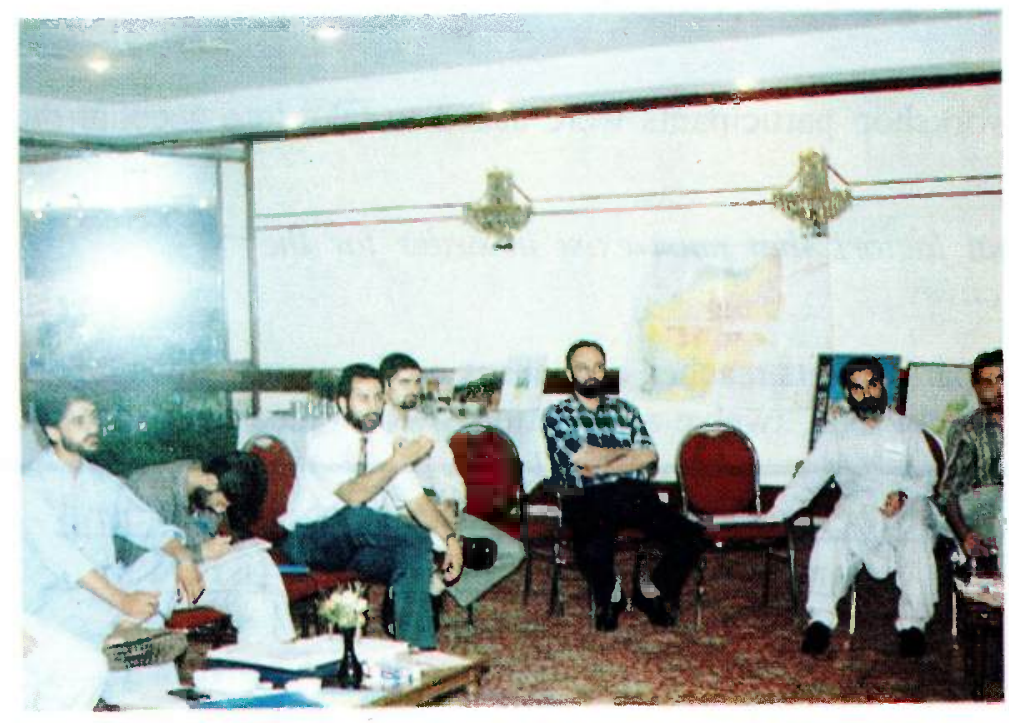

\section{Major Activities}

The group work approach was applied to identify and formulate major activities for each of the results.

The outcome of the group work was reviewed jointly by the workshop participants

During this review some of the activities were reformulated for clear understanding and few additional activity cards were added to the matrix, which in participants' opinion were expedient for the achievement of the results. For complete overview of the Logical Framework Matrix (PPM) of "Forest Programme" refer to Annex \#8.

\section{WORKSHOP EVALUATION AND ADJOURNMENT}

The last card writing exercise done by the participants was to evaluate the workshop Participants were asked to assess the workshop by giving their comments on cards about:

I. What was not good in the workshop and could be improved the next time. (critical comments)

II What did they like about the workshop? (positive comments)

In order to facilitate they were also presented the aspects to consider while giving their impression about the workshop. These included: workshop organisation (logistics), workshop objectives, their personal expectations, outcome/results of the workshop, methodology used, participation and role of the moderator/facilitator.

Critical comments were concerning the non-appearance of some important stakeholders, long working hours, short duration of the workshop, time lost due to long discussions on simple issues, non-provision of moderator's flip-charts, etc.

Overall, the workshop participants were very pleased with the outcome of the workshop and appreciated the participatory approach, organisation, methodology and facilitation and guidance provided by the moderator.

Comment cards written by the workshop participants are presented in Annex \#9. 


\section{Closing Remarks}

Maulawy Abdul Tawab Qazi Zada in his closing remarks congratulated the participants for achieving the objective of the workshop and also thanked AREA for timely organising the event that addressed the issue of deforestation. Appreciating the analytical and planning work, he mentioned that interesting and to the point discussions took place and the plan when implemented would bring benefits to people and the country both. He hoped that the donor community would join hands with the people. Islamic Emirate of Afghanistan (Government), NGOs and UN offices for realisation of the objectives. On behalf of the Ministry of Planning, he offered all sorts of co-operation and support; and expected that more such events would be organised as the current workshop is viewed as significantly substantial for the rehabilitation of national economy and conservation of environment.

Script of Maulawy Qazi Zada's remarks is presented in Annex \#10.

Later the workshop was adjourned by Mr. Rafaat Ludin with thanks to the participants for their valued contributions and hoped that the plan prepared by them would contribute towards the rehabilitation of Afghanistan. 


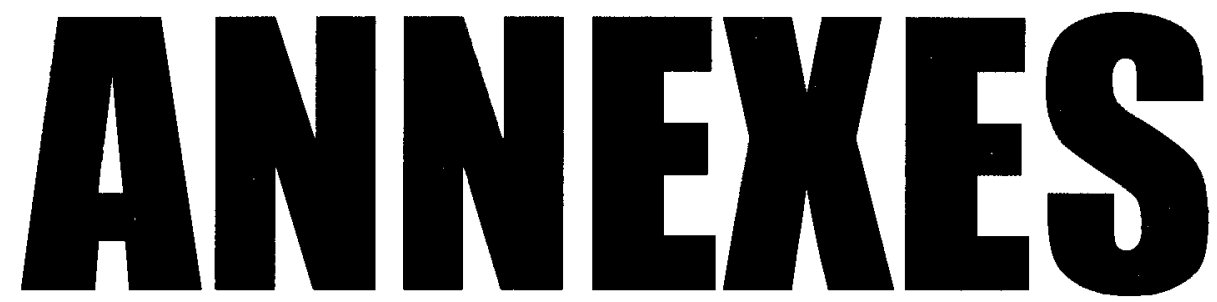

:

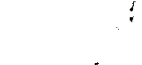

11 


\section{List of Workshop Participants}

No. Name

Organization

\section{Representatives from Government of Afghanistan:}

1. Mr. Abdul Tawab Qazi Zadah,

President of Foreign Relations

2. Mr. Abdul Fatah Ashna,

General Director of Cultural Relations

3. Mr. Shair Mohammad,

General Director of Forestry Department

4. Mr. Khawaja Abdul Basir,

Chief of Extension Department,

\section{UN Representatives:}

5. Mr. Matthew Owen,

Environment Consultant

6. Mr. Nabil Makki,

Head of Sub-office

7. Mr. Mohammad Shafi,

Programme Assistant

8. Mr. Abdul Haq Zia,

Design Engineer

\section{NOVIB Representative:}

9. Mr. Mohammad Ishfaq Khan,

Program Coordinator

\section{Baseline Survey Team:}

10. Prof. G. N. Nasery

11. Mr. Mohd Shuaib Partaw,

Remote Sensing / Survey Expert

\section{NGOs \& Others:}

12. Eng. Najibullah Akrami,

Deputy Director - Survey \& Planning

13. Mr. M. Ismael Nasri, Coordinator Forest Sector

14. Mr. M: A. Nazim

HRD Manager

15. Mr. Ajmal Rahi,

Member of Information Section
Ministry of Planning - Afghanistan.

Office of Foreign Relations Department,

Ministry of Planning, Kabul.

Ministry of Agriculture, Kabul

Ministry of Agriculture, Kabul.

UNCHR, Nairobi, Kenya.

UNCHR Jalalabad.

UNCHR, Islamabad.

FAO, Peshawar.

NOVIB, Peshawar

Kabul University - Baseline Surveyor

Baseline Surveyor

ADA, Peshawar

MADERA, Peshawar.

NPO/RRAA, Peshawar

CCA, Peshawar. 


\section{Annex \# 1}

\section{List of Workshop Participants}

No. Name

Organization

AREA Representatives:

16. Mr. Rafaat Ludin, Managing Director

17. Mr. Amin-ul-Haq Mayel,

Regional Manager

18. Mr. Mohd Massom,

Regional Manager

19. Mr. Sultan Maqsood Fazil, Admin. \& HRD Manager

20. Eng. Noor Ahmad Kamran, ACC Director

21. Mr. Ashraf Nassery, Community Development Coordinator

AREA

AREA, Herat

AREA, Kabul.

AREA, Peshawar

AREA, Peshawar.

AREA, Peshawar

22. Mr. Mohammad Ershad,

AREA, Peshawar. Monitoring and Evaluation Officer

23. Mr. Zabihullah Habibi, Finance Manager

24. Mr. Idrees Zaman

25. Mr. Kanishka Nawabi

AREA, Peshawar.

AREA, Peshawar

AREA, Peshawar

Workshop Facilitator:

26. Mahmood Hemani,

Freelance Consultant / Trainer

ViCAR - Development Management Consultant, Karachi. 


\section{Opening Statement Presented By \\ The Representative of Ministry of Agriculture, \\ The Islamic Emirate of Afghanistan \\ Mula Khawaja Abdul Basir}

Dear audience, guests and participants of the workshop,

Assalamu allaikum wa rahmatullah

First of all on behalf of the ministry of agriculture and livestock I would like to express my good wishes and complements. Welcoming dear guests I wish them more success in taking fruitful steps towards rehabilitation and energy conservation in Afghanistan.

Ministry of Agriculture of the Islamic Emirate of Afghanistan values such workshops and hopes for practical measurements by concerned authorities and NGOs towards energy conservation in Afghanistan.

Afghanistan is a landlocked and mountainous country 65,3 million hectares in dimensions out of which 7,9 million hectares are agricultural land, 30 million hectares are overlaid by postures, 24 million hectares are barren while only 9 million hectares are covered by forests. The population of Afghanistan is about 17.5 million, 15 percent of which are living in urban areas, and $70 \%$ in rural areas and $15 \%$ are nomads.

Level of knowledge in Afghanistan is very low where only $10 \%$ of population can read and write. Forests and agricultural lands are very limited and irrigation water is scarce limiting the possibilities of agriculture and forestry that means only $3 \%$ of the land is covered with forests. Not long ago a very large portion of Afghanistan's lands were covered with forests while very less is remaining which are indiscriminately and rigorously cut every day.

The importance of forests is not covert to any body in terms of climate regulations, rate of rainfall, storage of water, preventing soil erosion and severe floods, purifying air, improving environment and production of industrial and fuel wood.

Regarding the importance of forests' role in civilization of the nations and the climatic situation of Afghanistan having a vast dry and semi-dry region, the significance of forest conservation and forest rehabilitation plans can become clear and the necessity of implementing comprehensive schemes for industrial and fuel wood as well as changing the dry and ill-looking face of the deserts can be felt.

Therefore, in such circumstances, the Afghanistan forests, especially the industrial woods of eastern zone and the precious pistachio trees are being completely diminished. Although currently there are no reliable statistics at hand, however, still we can presume that during the last two decades more that a quarter of the 500 


\section{Annex \#2}

hectares of Afghanistan forests have been cut off while the rest are under indiscriminate cutting in Nuristan and Kunar provinces.

In such a case, as much as possible, the forests should be protected and by making man-made nurseries the increasing needs and pressure on cutting and harvesting of natural woods should be relieved.

On behalf of Ministry of Agriculture of the Islamic Emirate of Afghanistan I would like to suggest:

1. Kabul greenbelt: this project has been considered as the only systematic scheme of forestry because it focuses on watershed management aiming at controlling and restraining the water run off and preventing soil erosion besides reducing dust in Kabul suburbs and expanding beautiful and green atmosphere in the area to encourage improvement of environment.

2. Rehabilitation and reconstruction of Qargha Reservoir: to revive the forests on the hills and areas surrounding Qargha dam. Additionally Paghman hills that were among the most significant Afghan public parks at national and international levels, will be rehabilitated while subsiding of mud in Qargha dam will be prevented lengthening the age of the dam.

3. Adopting an effective strategy for protection and conservation of industrial woods of eastern zone and the closed forests of northern area because these forests are irrationally being harvested and are vanishing.

Thanks for your attention 


\section{A Brief on: \\ The Present Status of the Southeast Forests of Afghanistan}

\section{Survey system:}

The level of loss and damage, occurred inside these forests during the past 28 years in each of the five Provinces is evaluated and compared according the following methods:

1. Utilization of land cover maps of Afghanistan, prepared through interpretation of satellite images.

2. Visit of different forest areas to get information on the general status of the forests.

3. Making practical measurement of the trees in the forest: areas to find out their compositions, form, density, age and productivity.

4. Determination of annual wood amount consumed by families, social establishments, governmental organization in Kabul and other provinces of southeast part of Afghanistan.

In connection with this, different other scientific materials, survey of natural forests of Afghanistan conducted in the year 1971 have also been taken into consideration. 
Annex \#3

Part $A$ by Prof. Nassery 26

\section{Types of Forest Areas in Afghanistan}

As the subject of present survey is concentrated only on constructive forests of Afghanistan, it must be said that these forests form six ecological zones in which the following forests exist:

\section{Olive}

2. Oak

3. Pine

4. Cedar

5. Spruce

6. Juniper 


\section{Usage / Users}

Timber Merchants, capital cities of southeast Provinces, including Kabul City, Government organizations, social establishment, and villages within and surrounding forest areas are the main wood consumers.
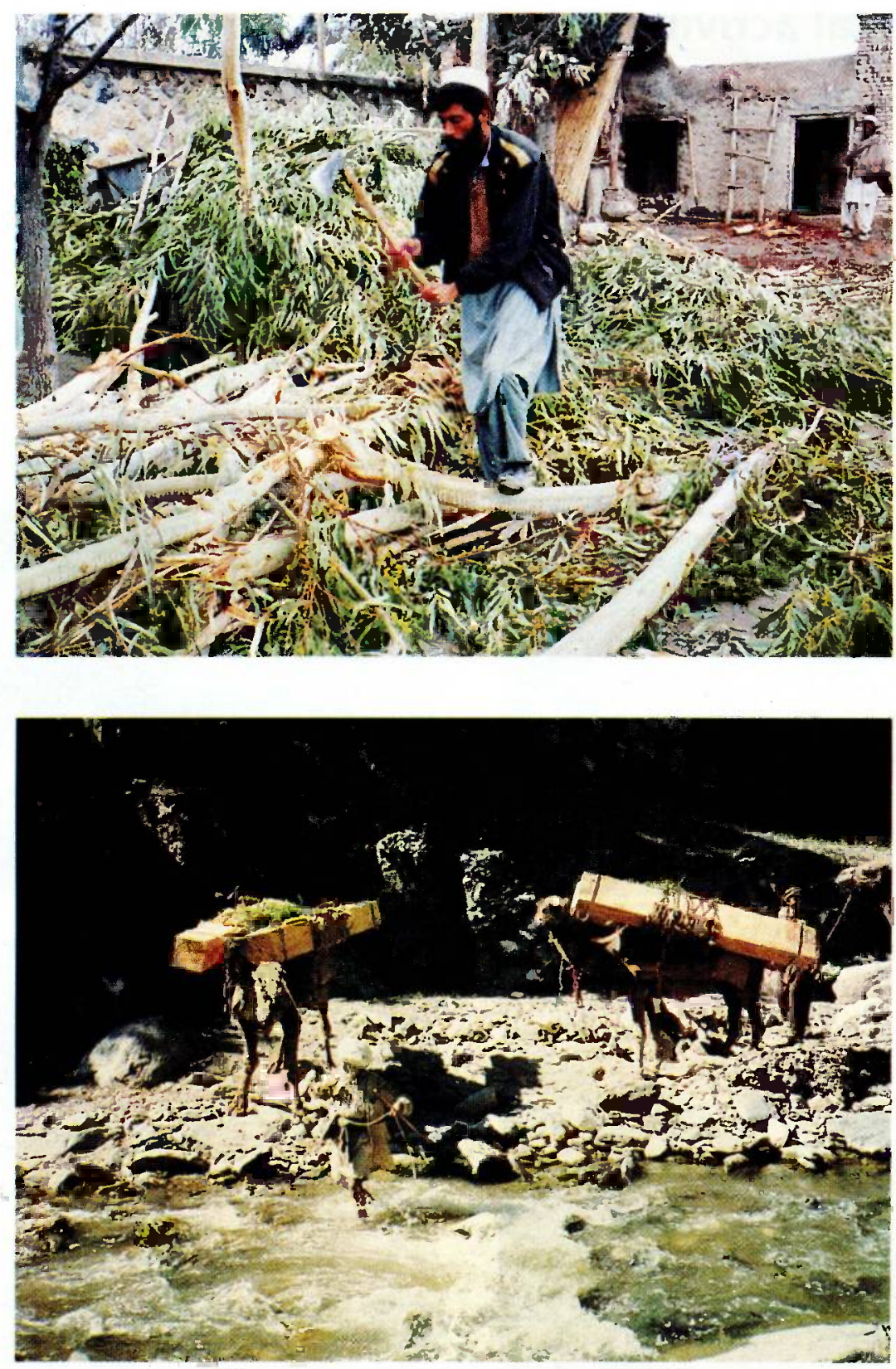


\section{Annex \#3}

Part A - by Prof. Nassery $4 / 6$

\section{Consequences of Deforestation}

Deforestation as it is happening in the area under the study will cause economical and biological damages. This will affect economical values such as:

\section{Wood production}

2. Biological activities

- regulation of water regime

- prevention of soil erosion

- $\quad$ protection of habitation from floods or strong winds

- creation of sound atmosphere for human and wildlife
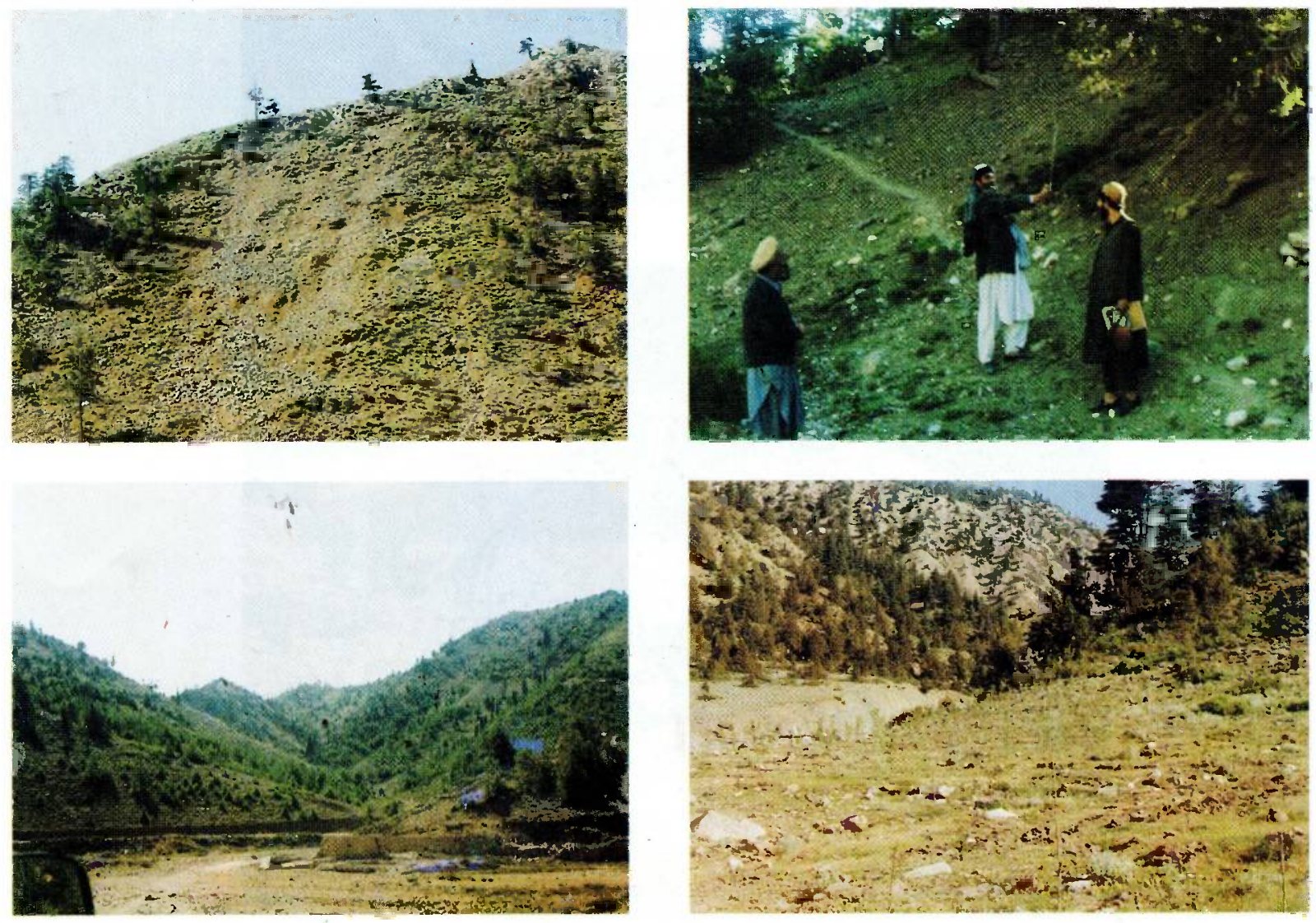


\section{Natural Regeneration}

Due to natural reforestation the whole forest areas have been covered by young stands (new generation) of trees with ages between 2 and 30 year, averaging some 15-17 years. However these are not capable of natural regeneration, are too densely grown to enable a suitable growth.

In some parts of the forests, the wood hunters have already started to axe off the young stand, which will result in ZERO regeneration and thus complete devastation of the forest areas leading to Complete Dissertification

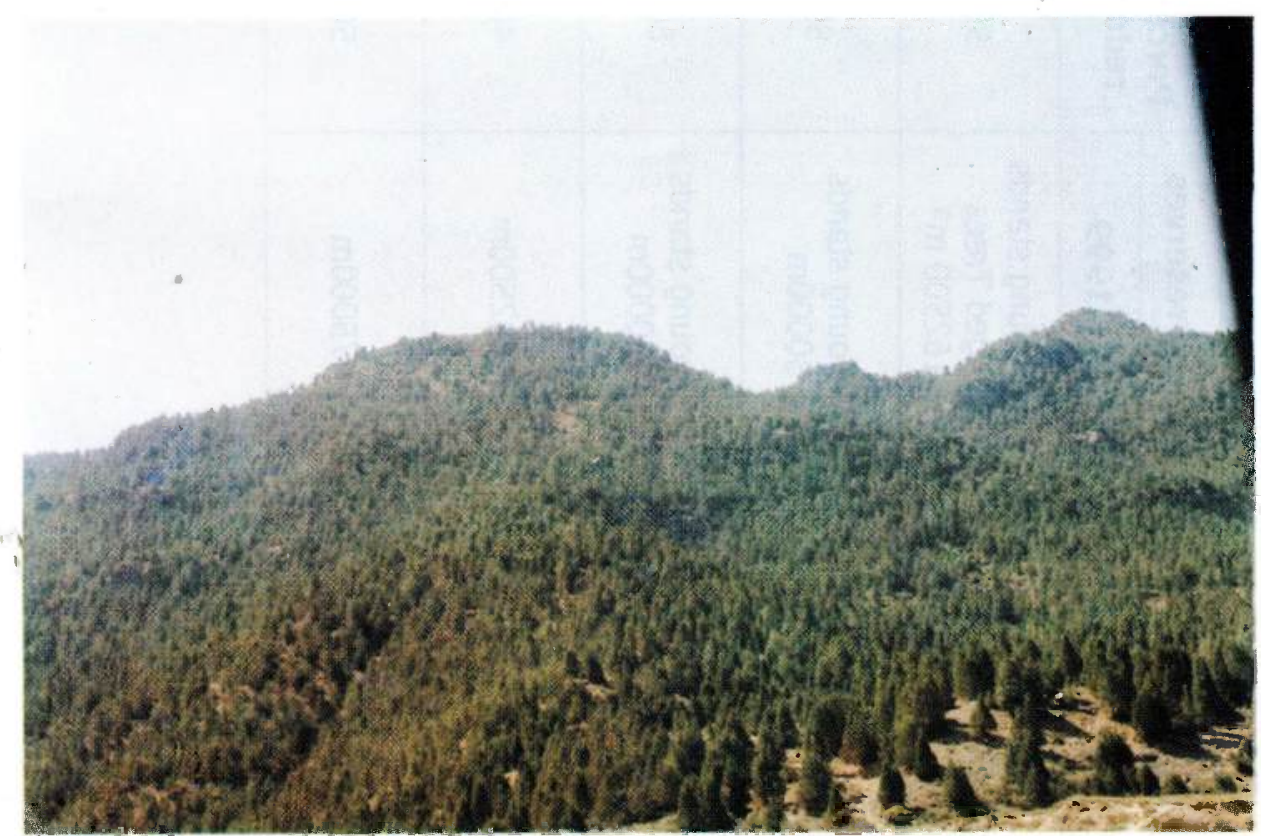


Part $A-$ by Prof. Nassery $6 / 6$

\begin{tabular}{|c|c|c|c|c|c|c|}
\hline$\frac{8}{y}$ & $\frac{5}{8}$ & O̊̊ & 능 & ర్రి & $\stackrel{\text { Ln }}{\stackrel{D}{N}}$ & $\stackrel{+}{\circ}$ \\
\hline $\begin{array}{l}\frac{5}{0} \\
\frac{d}{2} \\
\alpha\end{array}$ & $\begin{array}{l}\frac{5}{8} \\
\frac{8}{8} \\
\frac{8}{8} \\
\frac{0}{8}\end{array}$ & 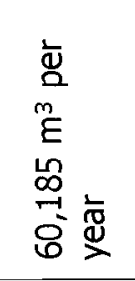 & 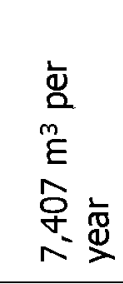 & 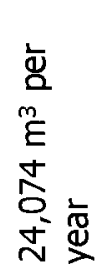 & 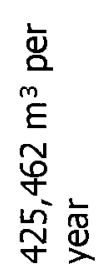 & 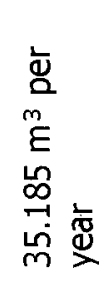 \\
\hline $\begin{array}{l}5 \\
0 \\
y \\
\frac{4}{3} \\
8 \\
\frac{8}{0} \\
\frac{0}{80} \\
\frac{0}{2}\end{array}$ & $\frac{5}{0}$ & 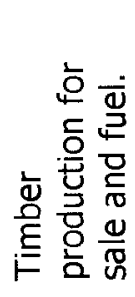 & 음 & 음 & 응 & 음 \\
\hline & $\begin{array}{l}\frac{3}{3} \\
\frac{3}{5} \\
\frac{5}{2}\end{array}$ & 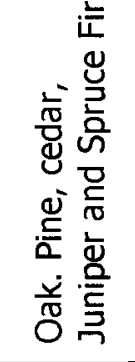 & 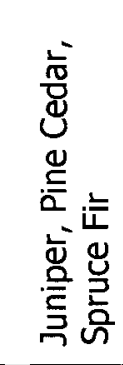 & 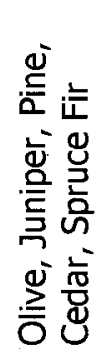 & 음 & 음 \\
\hline \multicolumn{2}{|c|}{ 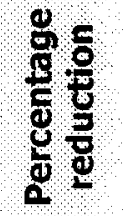 } & ㅇํㅇ & $\begin{array}{l}\stackrel{0}{\circ} \\
\text { 员 }\end{array}$ & চे & ㅇํㅇ & 옹 \\
\hline \multirow{2}{*}{ 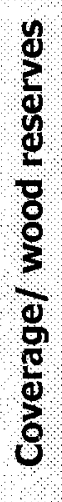 } & $\begin{array}{l}9 \\
8 \\
\end{array}$ & 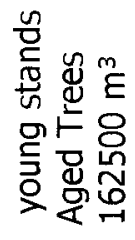 & 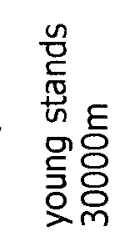 & 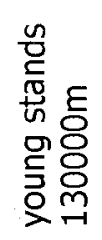 & 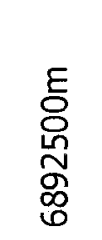 & 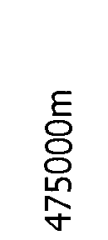 \\
\hline & $\frac{1}{9}$ & 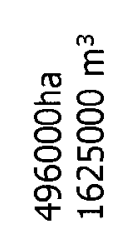 & 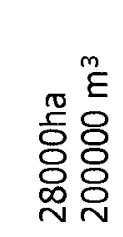 & 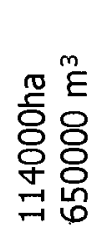 & 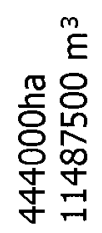 & 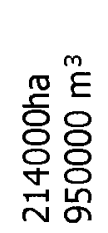 \\
\hline \multicolumn{2}{|c|}{ 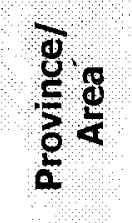 } & $\frac{\frac{\pi}{2}}{\frac{y}{0}}$ & 옹 & $\begin{array}{l}\frac{\pi}{2} \\
\frac{2}{2} \\
\frac{0}{0} \\
\frac{0}{2} \\
2\end{array}$ & $\frac{5}{5}$ & 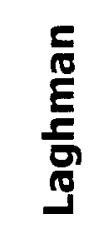 \\
\hline
\end{tabular}




\section{Agency for Rehabilitation and Energy-conservation in Afghanistan (AREA)}

\section{Use of the Digital Land Cover Database of Afghanistan in the "Survey of Present Status of South East Forests of the Country"}




\section{Introduction:}

This paper is designed to provide some information on the above Database elaborated by FAO, Rome, based on interpretation of satellite imageries (Lansat TM, KFA-1000, Spot) utilizing also aerial photographs, topographic maps, and land cover maps from the data 1972 with close cooperation of Afghan Geodesy and Cartography Head Office (AGCHO).

The outcome of the mentioned database is at present available at ProMis/UNDP/Afghanistan in the form of land cover maps, photo maps, and atlases at different scales and also land cover statistical Tables.

This work was carried out during the years 1990-1996 through the Project AFG/90/002 "Utilization of Remote Sensing for Inventory and Monitoring of Agricultural Land in Afghanistan". The Project was sponsored by UNDP/Afghanistan and implemented by FAO, Rome.
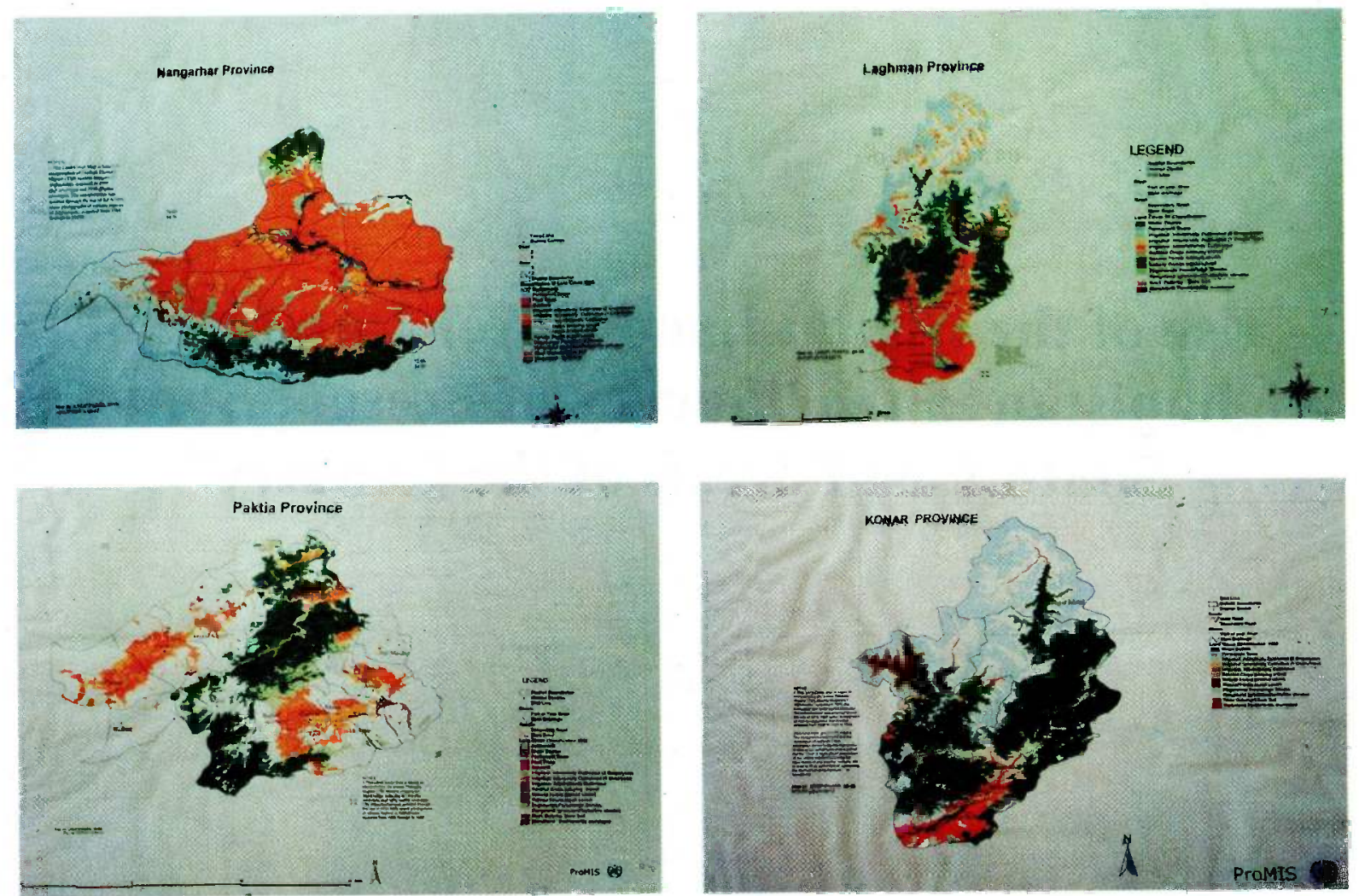

\section{Objective:}

The project aimed at producing land cover maps at 1:100,000 and 1:250,000 scales and statistics for agricultural land to compare the historical and current situation and land utilization as basis for planning and rehabilitation of agricultural and other natural resources sectors.

\section{Background:}

Detailed countrywide land cover maps of Afghanistan were not available for a long time. However, in the past years, some relevant institutions of the Ministries of Mines and 


\section{Annex \#3}

\section{Part $\boldsymbol{B}$ by $M$. Shuaib Partaw $3 / 5$}

Industries, Ministry of Agriculture, Cadastral Survey Institute, Ministry of Housing and Town Planning, the Kabul Municipality, etc. were involved in conducting surveys for preparation of land cover maps. These were, however, of special cover types of their own interest from limited areas in order to have a record of interesting features to be used as a reference for their official work. It should be pointed out that some countrywide or considerably of larger extent surveys were also made from which preparation of Geologic Map of Afghanistan at the scale of 1:500,000 and completion of $30 \%$ cadastral mapping, preparation of agricultural and forest maps of all forest areas of Afghanistan can be mentioned as an example here.

The $\mathrm{AGCHO}$, as a Government central mapping organization, being professionally engaged in establishing Horizontal \& Vertical Control networks throughout the country for topographic mapping, using high precision instruments and equipments needed for higher Geodetic/Stereo Photogrammetric surveys, assisted the above institutions in their work with providing topomaps, topoplans, photomaps, photomosaics, aerial photographs of different scales produced by this organization. However until the beginning of 1972 , countrywide land cover maps with more cover types was not prepared. During the mentioned year, contacts were established between the Ministry of Agriculture and AGCHO for elaboration of a land cover map with two important cover types (Agricultural land and Gardens) to be implemented at AGCHO using fresh aerial photographs. This work started in 1972 through organizing several interpreting teams each assigned for a Province. The photographs were interpreted through stereoscopic three-dimensional viewing, which ultimately resulted in accurate interpretation and pattern recognition. In the meantime ground truthings were also made during different seasons to verify the degree of accuracy of the work. Results of interpretation and comparison were later transferred onto 1:100,000 topographic maps on corresponding areas and each cover type were inked with different colors.

Finally, as a result of this project, a land cover map at the national level with the following classes was prepared which was later used as a good source of data by many concerned institutes for many years:
Class-1
Class-2
Gardens: (cover I)
Class-3
First grade irrigated land, followed by rice cultivation: (cover II)
Second grade irrigated land, wheat farming followed by corn and mug bean cultivation.
Class-4 Third grade irrigated land only wheat farming (one crop per year)
Class-5
Fourth grade irrigated land, cultivated every other year.
Class-6
Class-7
Fifth grade land, irrigated only one or two interval.
Sixth grade irrigated only in spring but deprived of water throughout other seasons of the year.
Class-8 Seventh grade rain fed flat land.
Class-9 Eightth grade rainfed slopping land.

\section{Development of Recent Digital Database for Afghanistan:}

Development of recent Digital Database (1990-1993), which was given a brief information on earlier, is a comprehensive one, with more important cover types that are mentioned as follows: 


\section{a) Urban Areas:}

- Settlements and associated non-agricultural land.

b) Orchards:

- Fruit trees.

- Vine yards

- Gardens (ornamental and fruit trees inside settlement)

c) Irrigated Agricultural Lands:

- Intensively cultivated Class-1 (2crop/year), wheat followed by rice

- Intensively cultivated Class-2 (2 crop/year), wheat followed by other crops

- Occasionally cultivated/abandoned Class-3 (Every 2 to 3 years generally wheat.

d) Rainfed Agricultural Land:

- Cultivation in flat lying areas.

- Cultivation in slopping areas.

e) Commercial Forests:

- Pistachio trees (closed cover).

- Pistachio trees (opened cover).

f) Natural Forests:

- (Closed Cover).

- (Opened Cover).

- (Degenerated Forests/High Shrubs).

g) Range Land:

- Low shrub/grass land and Forbes (from open to closed cover).

h) Barren Land:

- Bare Soil/Rock outcrop or sparsely vegetated areas.

- Sand-covered areas.

- Sand dune.

i) Marsh/Swamp Areas:

- Permanent inundated.

- Intermittently inundatèd.

j) Water Bodies:

- Lakes, etc

\section{k) Permanent snow.}

\section{Use of the above mentioned Land Cover Maps in the "Survey on Present Status of Southeast Forests of Afghanistan":}

Learning that these materials; were available at ProMis/UNDP/Afghanistan, efforts were made by AREA to acquire the materials and to make use of them in the above-mentioned sürvey. 


\section{Annex \#3}

\section{Part B - by $M$. Shuaih Partaw 5/5}

First of all, a forest map of southeast Province was sketched and prepared with geographical coordinates at the scale of 1:1,250,000 using the same scale land cover map of Afghanistan, elaborated based on interpretation of Landsat TM, KFA-1000 images taken between the years 1989-1993. With respect to geographical coordinates of the above sketched map, all forest areas in all southeast Provinces were identified and delineated. Then topographic maps of corresponding areas were provided by AREA in order to make further studies regarding relief and topographic situations of the area under the study and prepare a comprehensive reconnaissance plan and select visiting sites. These topographic maps were also used in travelling directly to the selected sites through shortest and easiest routes. Utilizing the same maps, the forest zonations and stages as defined in the survey report were studied and their relative heights above the sea level were determined. Furthermore, 1:250,000 land cover maps of the above Provinces were acquired form ProMis. One of the most important cover on these maps were natural forests classified in three classes consisting of closed cover, open cover, and degenerated forests/high shrubs.

These maps were considered to be highly useful for the survey. Therefore, they were studied with keen interest and comparisons with previous studies (1972 Survey by GTZ) in respect to the forest areas were made.

Finally, most recent statistics regarding the area of southeast forests of Afghanistan were provided for analysis and comparison from 1993 land cover statistics Tables already developed by the Project AFG/90/002, presently available at ProMis.

In order to be able to finally developed the status quo of the forest resources and reflect the level of damage and destruction therein, an actula survey of the south east forest resources were carried out, the result of which is also annexed to this report.

\section{References:}

1. Report on Attendance in UNDP-Financed FAO Training course in Rome, Italy. Submitted to Mr. D.E Lockwood UNDP/Afghanistan Resident Representative Kabul, June 1994 by Mr. Shuaib Partaw.

2. Database Documentation, Published by FAO Rome, 1993.

3. AFG/90/002 Technical Project Documents. 


\section{Introduction of Participants and their Expectations}

\begin{tabular}{|c|c|c|}
\hline Name \& Designation & Organization, Location & Workshop Expectation(s) \\
\hline $\begin{array}{l}\text { Mathew Owen, } \\
\text { Environment Consultant }\end{array}$ & UNHCR, Nairobi, Kenya & $\begin{array}{l}\text { Confirmation of environmental problems and } \\
\text { solution in returnee area for UNHCR support. }\end{array}$ \\
\hline $\begin{array}{l}\text { Nabil Makki, } \\
\text { Head of Sub-office }\end{array}$ & UNHCR, Jalalabad. & $\begin{array}{l}\text { To identify environmental problems and } \\
\text { propose solutions (if possible). }\end{array}$ \\
\hline $\begin{array}{l}\text { Sultan Maqsood Fazil, } \\
\text { Admin. \& HRD Manager }\end{array}$ & AREA, Peshawar & $\begin{array}{l}\text { To develop a realistic and applicable strategy } \\
\text { addressing the rapid deforestation problems } \\
\text { in Afghanistan }\end{array}$ \\
\hline $\begin{array}{l}\text { Mohammad Shafi, } \\
\text { Program Assistant }\end{array}$ & UNHCR, Islamabad & $\begin{array}{l}\text { To be able to know how environmental } \\
\text { degradation affects our (UNHCR) target } \\
\text { beneficiaries }\end{array}$ \\
\hline $\begin{array}{l}\text { Noor Ahmad Kamran, } \\
\text { ACC Director }\end{array}$ & AREA, Peshawar & $\begin{array}{l}\text { To workout a strategy which will reduce } \\
\text { deforestation and enhance afforestation. }\end{array}$ \\
\hline $\begin{array}{l}\text { Zabihullah Habibi, } \\
\text { Finance Manager }\end{array}$ & AREA, Peshawar & $\begin{array}{l}\text { To develop a realistic and achievable } \\
\text { strategy. }\end{array}$ \\
\hline $\begin{array}{l}\text { Abdul Haq Zia, } \\
\text { Design Engineer }\end{array}$ & FAO, Peshawar & $\begin{array}{l}\text { To find a solution for problems of } \\
\text { deforestation in Afghanistan. }\end{array}$ \\
\hline $\begin{array}{l}\text { Ashfaq Khan, } \\
\text { Program Coordinator }\end{array}$ & NOVIB, Peshawar & $\begin{array}{l}\text { Information about current situation of forestry } \\
\text { in Afghanistan and developing a strategy to } \\
\text { improve upon it. }\end{array}$ \\
\hline $\begin{array}{l}\text { Rafaat Ludin, } \\
\text { Managing Director. }\end{array}$ & AREA, Peshawar & $\begin{array}{l}\text { To develop a workable strategy for revival of } \\
\text { Afghanistan's forests resources. }\end{array}$ \\
\hline $\begin{array}{l}\text { Ajmal Rahi, } \\
\text { Member of Information } \\
\text { Section. }\end{array}$ & CCA, Peshawar & $\begin{array}{l}\text { To be practically productive in the } \\
\text { reforestation process. }\end{array}$ \\
\hline $\begin{array}{l}\text { Najibullah Akrami, } \\
\text { Survey \& Planning Deputy } \\
\text { Director }\end{array}$ & ADA, Peshawar & $\begin{array}{l}\text { Developing a comprehensive strategy } \\
\text { document for stopping deforestation and } \\
\text { promoting reforestation and afforestation }\end{array}$ \\
\hline $\begin{array}{l}\text { M. A. Nazim, } \\
\text { HRD Manager }\end{array}$ & $\begin{array}{l}\text { NPO/RRAA, University } \\
\text { Town, Peshawar }\end{array}$ & $\begin{array}{l}\text { Designing a plan for protection and } \\
\text { development of forests. }\end{array}$ \\
\hline $\begin{array}{l}\text { Gh. N. Nassery, } \\
\text { Professor }\end{array}$ & Kabul University, Kabul. & $\begin{array}{l}\text { Finding possibilities for rehabilitation of } \\
\text { natural forests in Afghanistan. }\end{array}$ \\
\hline $\begin{array}{l}\text { Mohd. Shuaib Partaw, } \\
\text { Remote Sensing / Survey } \\
\text { Expert }\end{array}$ & AREA, Peshawar & $\begin{array}{l}\text { Finding possibility for prohibition of } \\
\text { indiscriminate woodcutting. }\end{array}$ \\
\hline $\begin{array}{l}\text { M. Ismael Nasri, } \\
\text { Coordinator Forest Sector }\end{array}$ & MADERA, Peshawar & $\begin{array}{l}\text { The workshop focuses on Environment in } \\
\text { Afghanistan and particularly the forest. }\end{array}$ \\
\hline
\end{tabular}


Annex \#4

\section{Introduction of Participants and their Expectations}

Page 2/2

\begin{tabular}{|l|l|l|}
\hline \multicolumn{1}{|c|}{ Name \& Designation } & Organization, Location & \multicolumn{1}{c|}{ Workshop Expectation(s) } \\
\hline $\begin{array}{l}\text { M. A. Tawab Qazi Zadah, } \\
\text { President of Foreign } \\
\text { Relations }\end{array}$ & $\begin{array}{l}\text { Ministry of Planning, } \\
\text { Kabul }\end{array}$ & $\begin{array}{l}\text { Exploring ways to protect the forestland in } \\
\text { Afghanistan }\end{array}$ \\
\hline $\begin{array}{l}\text { Mullah Shair Mohd, } \\
\text { General Director of Forestry } \\
\text { Department }\end{array}$ & $\begin{array}{l}\text { Ministry of Agriculture, } \\
\text { Kabul }\end{array}$ & $\begin{array}{l}\text { To find practical solutions for protection of } \\
\text { forests in Afghanistan }\end{array}$ \\
\hline $\begin{array}{l}\text { M. Masoom, } \\
\text { Regional Manager }\end{array}$ & AREA, Kabul & $\begin{array}{l}\text { To have a clear idea on how to take practical } \\
\text { steps for protection and rehabilitation of } \\
\text { forests in Afghanistan as well as solving the } \\
\text { environmental problems }\end{array}$ \\
\hline $\begin{array}{l}\text { A. Fatah Ashna, } \\
\text { Reneral Director of Cultural }\end{array}$ & $\begin{array}{l}\text { Office of Foreign } \\
\text { Relations Department, } \\
\text { Ministry of Planning, } \\
\text { Kabul }\end{array}$ & $\begin{array}{l}\text { Finding ways to protect forests from illegal } \\
\text { cutting }\end{array}$ \\
\hline $\begin{array}{l}\text { Basir Ahmad, } \\
\text { Chief of Extension Dept. }\end{array}$ & $\begin{array}{l}\text { Ministry of Agriculture, } \\
\text { Kabul }\end{array}$ & $\begin{array}{l}\text { Coordination of reforestation program among } \\
\text { NGOs and Islamic Emirate of Afghanistan. }\end{array}$ \\
\hline $\begin{array}{l}\text { Mohammad Ershad, } \\
\text { Monitoring and Evaluation } \\
\text { Officer }\end{array}$ & AREA, Peshawar \\
\hline $\begin{array}{l}\text { Amin-ul-Haq Mayel, } \\
\text { Regional Manager }\end{array}$ & AREA, Herat & $\begin{array}{l}\text { Realistic plan for reforestation of forest land } \\
\text { in Afghanistan. }\end{array}$ \\
\hline
\end{tabular}




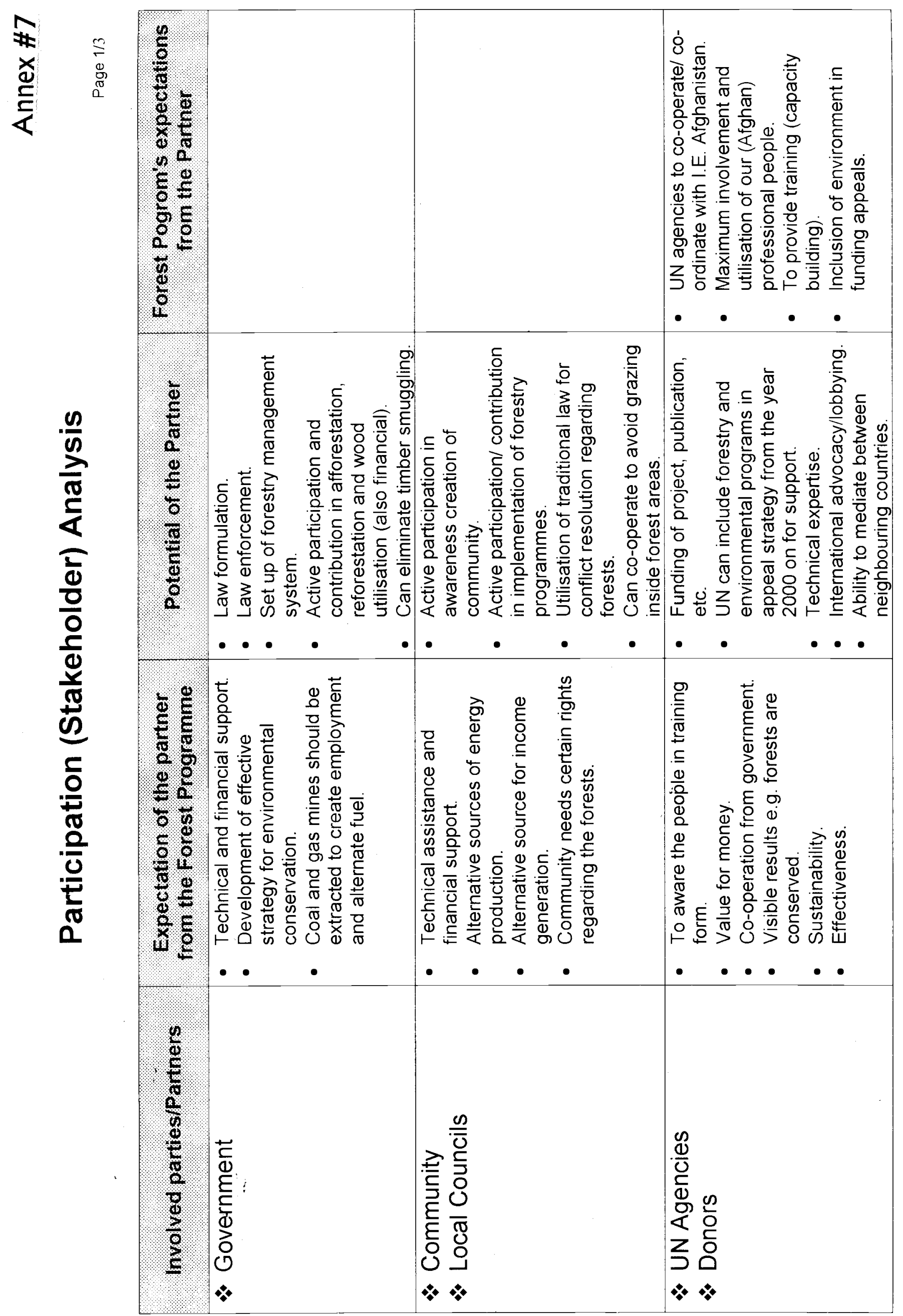




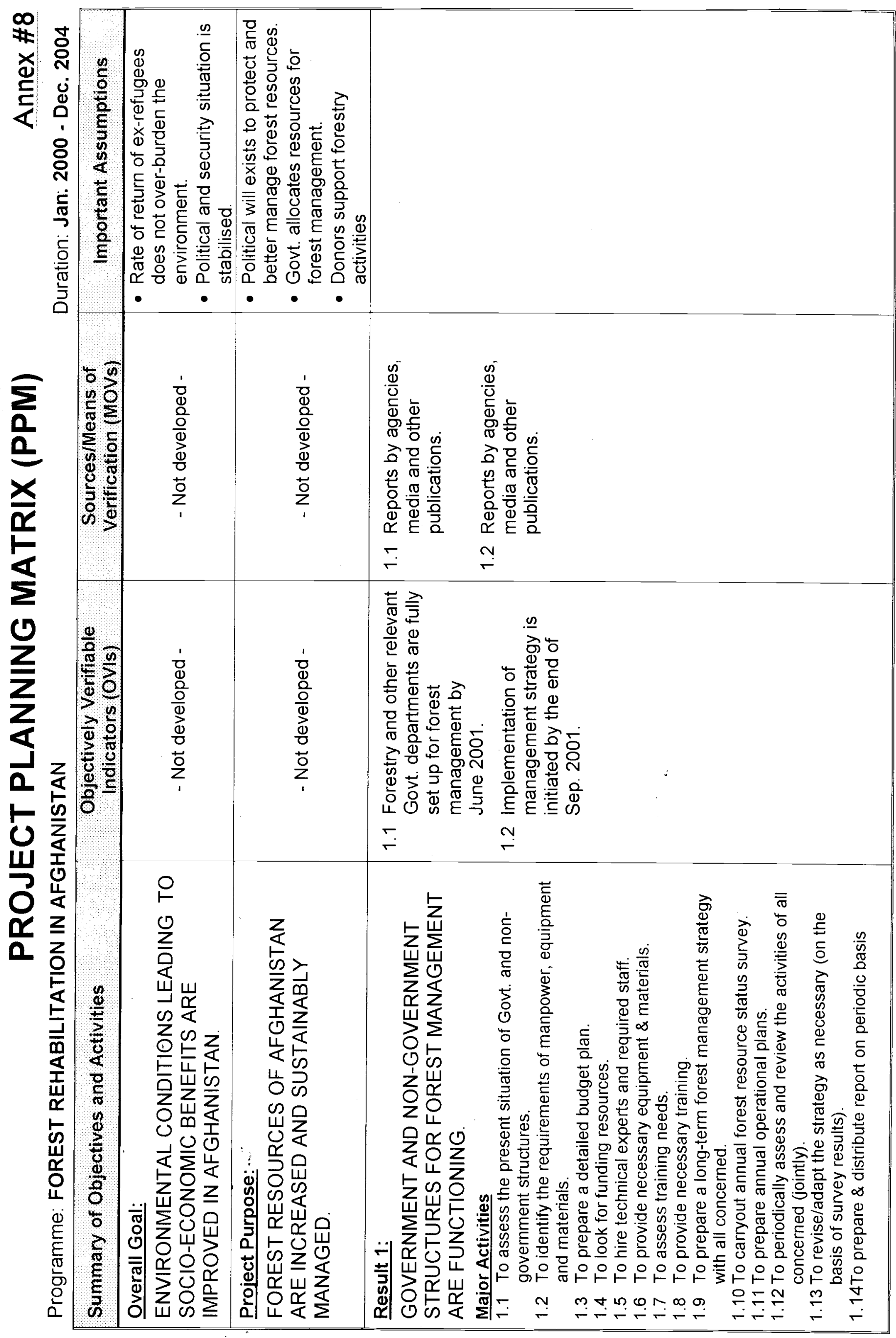




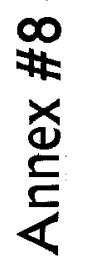

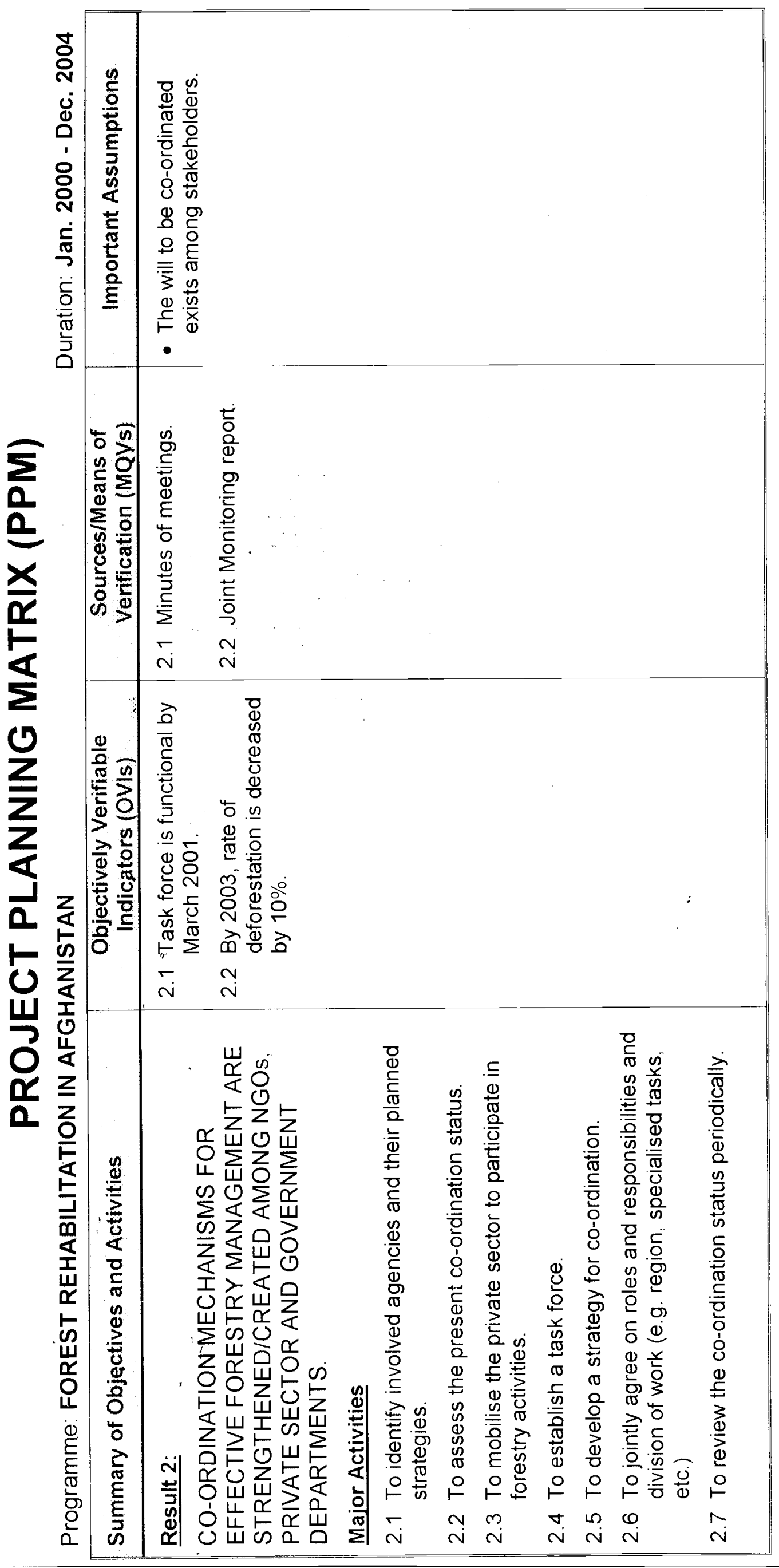




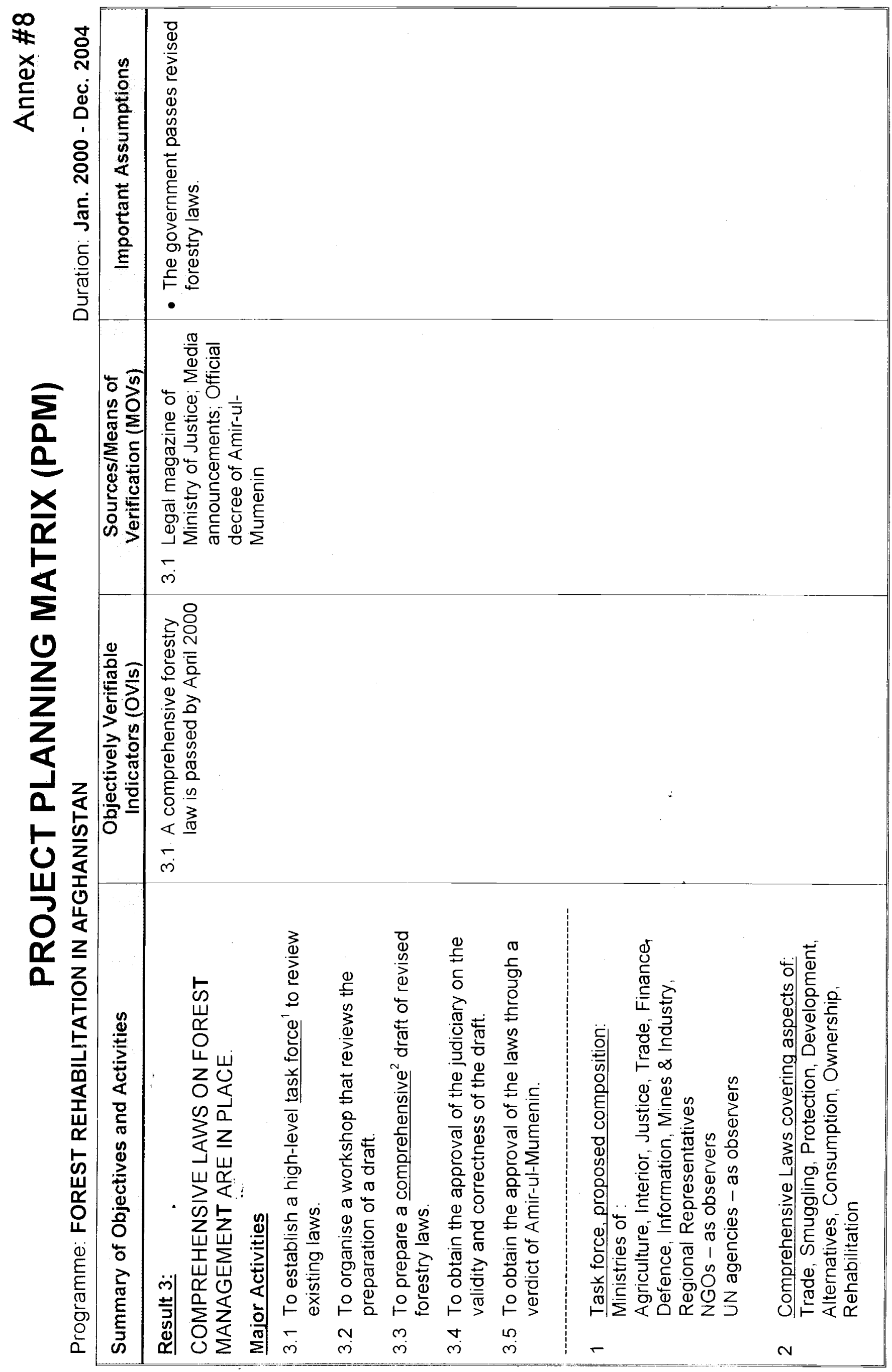




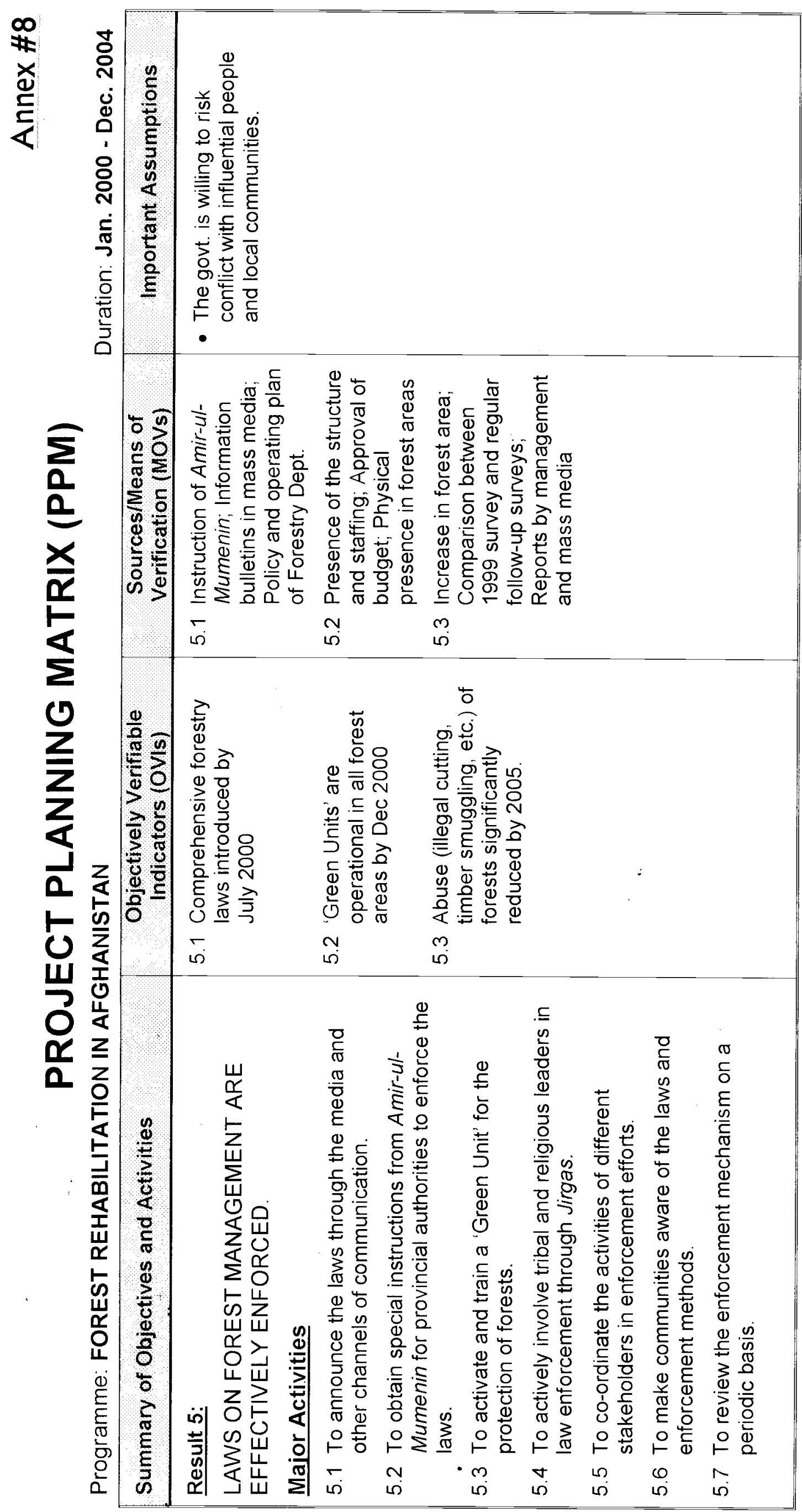




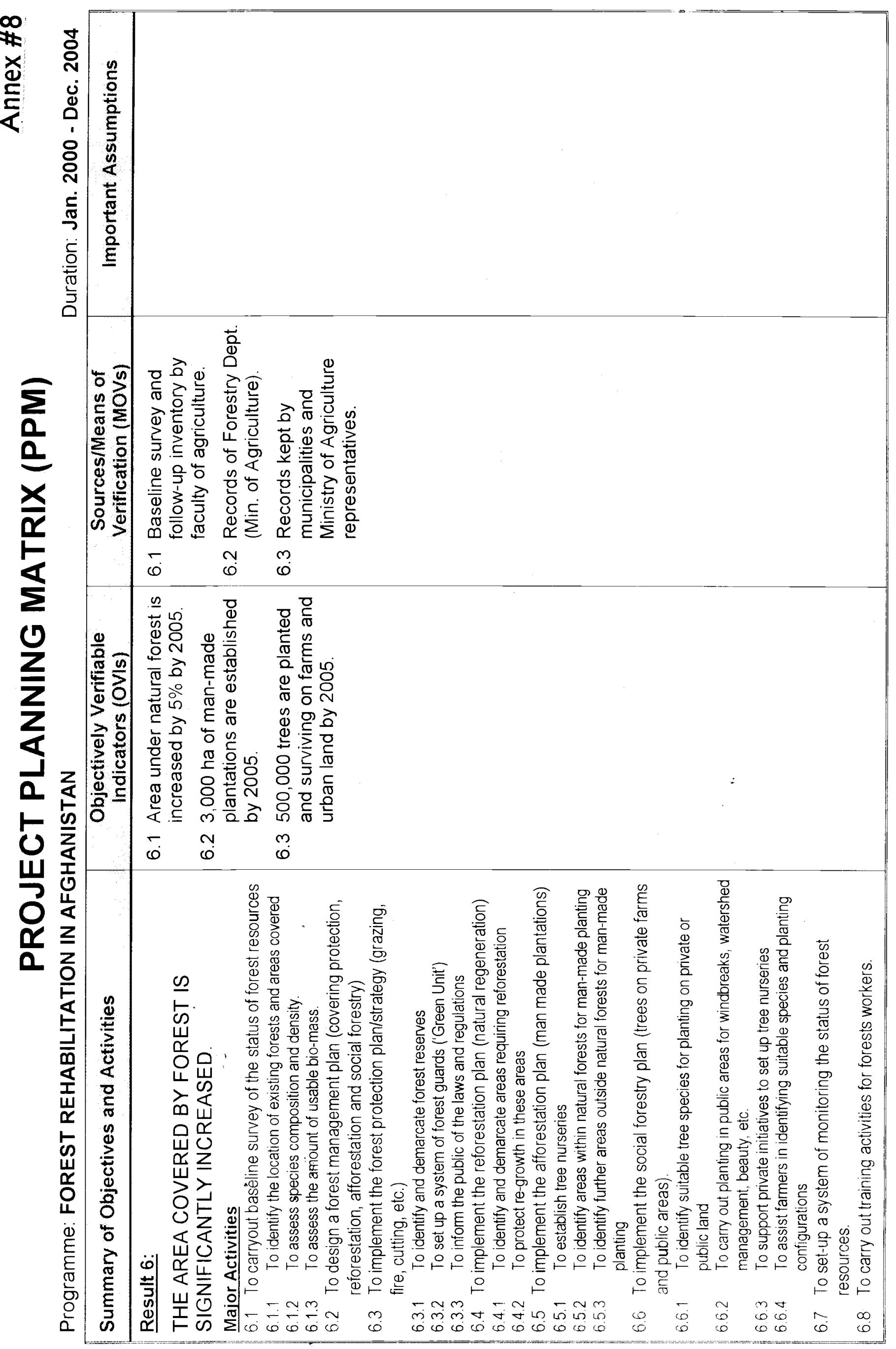




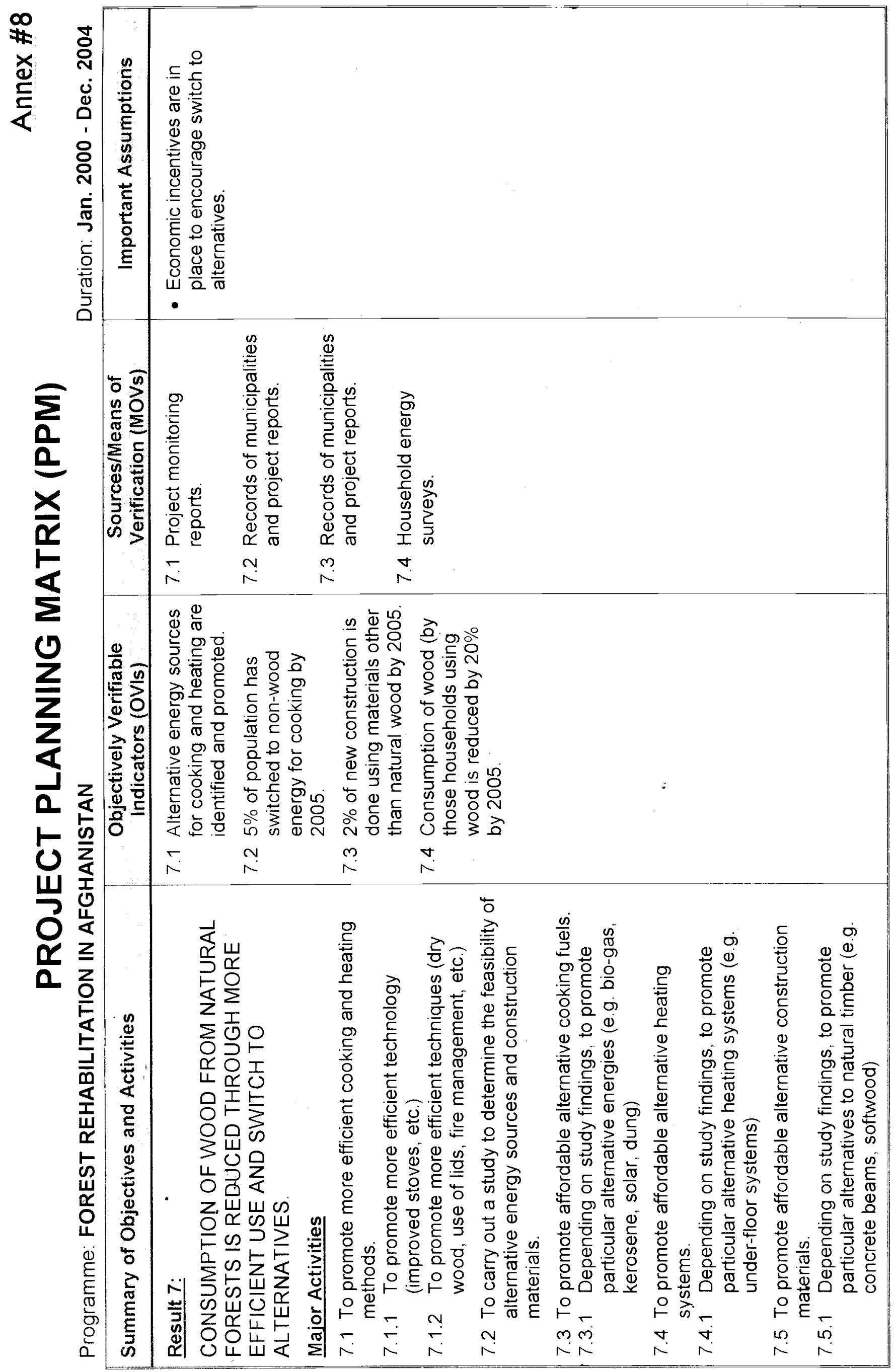




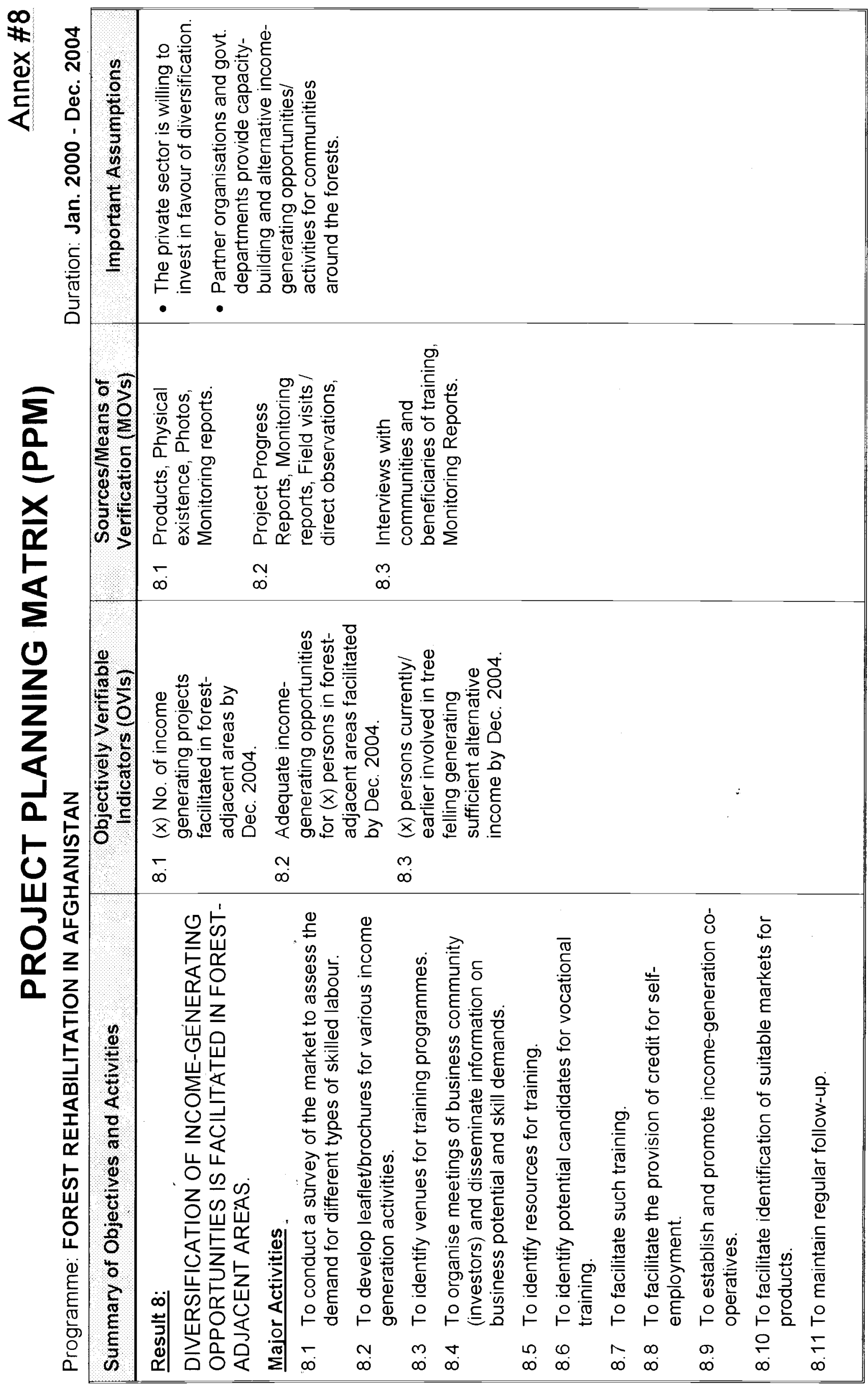




\section{Workshop Evaluation}

\section{What was not liked?}

- All expected participants did not come.

- Some important stakeholders didn't come (UNDP, UNEP, etc.).

- More donors should have been called.

- Late coming of some participants was not good.

- The time of the workshop was short and not enough.

- Many people who were invited didn't attend the workshop.

- No handout of the planning process (ZOPP flip charts).

- Different levels of understanding.

- Some of the donors and some UN agencies didn't send their representatives.

- Lack of handout of the program (ZOPP flip charts).

- Some of the participant arrived every day $10 \mathrm{~min}$. late.

- Workshop for Afghanistan to be held in Afghan language.

- Unnecessary shooting of pictures.

- Time frame was short (for the workshop).

- Role of government authorities is not very clear; priority is not given to it.

- Time frame for implementation is too lengthy.

- Role of professional participants was insufficient.

- Participation was insufficient by the participants.

- Less practical work by the participants.

- More than enough discussion on a simple issue.

\section{What was good and liked by you?}

- Contribution of participants was "GOOD".

- Good Facilitator, good methodology and well conducted.

- The presentation / classification of issues were good and systematic.

- Excellent moderation.

- Moderation was excellent!

- Fair and even work by the moderator (let participants lead).

- The matters were good scheduled.

- The workshop included all necessary points and explanations.

- Best participation of participants in all process (steps) of workshop.

- Good atmosphere, every one got the chance to participate actively. 


\section{Annex \#9}

\section{Workshop Evaluation}

\section{What was good and liked by you?}

- Everything was excellent with the workshop.

- Group working and active participation of the participant was very good.

- The outcome is very clear.

- What absorbed me very much in this workshop were the open group participation and the ZOPP system.

- Chance to see how good development projects are put together (ZOPP method).

- It was very informative and I found solution to my problem for project formulation and designing.

- Participation of government representatives from IEA and UN bodies (FAO + UNHCR).

- All the issues in workshop were thoroughly explained.

- The workshop was very constructive.

- The workshop was very beneficial and it has ended with good results.

- The view of the swimming pool was fantastic (sometimes).

- Atmosphere of participation was excellent!

- Participants were not always experts in the relevant field.

- Well organized and efficiently carried out.

- I gained what I expected from the workshop.

- I think this workshop's result will contribute towards stopping deforestation and was an excellent workshop. 


\title{
Closing Statement Presented By The Representative of Ministry of Planning, The Islamic Emirate of Afghanistan
}

\author{
Maulawy Abdul Tawab Qazi Zada
}

The participants of the environment workshop

\section{Assalamu Allaikum Wa Rahmanullah,}

First of all 1 would like to congratulate the successful completion of the workshop to you and the organizer, AREA.

The subject of the workshop was really very much interesting and to the point especially at a time when our forests are drastically diminishing and deforestation is affecting the environment in the worst form and in different ways. Fortunately, the majority of the participants of this workshop are scholars and experts who discussed the subject very scientifically and in an open atmosphere.

During four days of the workshop, interesting discussions took place by the participants regarding the causes of deforestation and its negative effects on environment and national economy whereas routes and ways of prevention of deforestation were sought, classified and highlighted the implementation of which certainly brings about favorable results.

We hope the implementation of this workshop in the light of full cooperation between people, Islamic Emirate of Afghanistan, NGOs, and UN offices prove very fruitful to prevention of deforestation in Afghanistan.

The Ministry of Planning of the Islamic Emirate of Afghanistan, while ready for any sort of cooperation and waiting for more seminars like such, considers the holding of the current workshop as significantly substantial towards rehabilitation of national economy and conservation of environment.

We expect that the decisions and ratification of this workshop be in harmony with the developmental plans of the country and get practical aspects.

It is worth mentioning that the manner of organizing the workshop by AREA with long background of service is appreciable. The hospitality render to the representatives (guests) of the Islamic Emirate of Afghanistan by AREA staff particularly Mr. Ludin is to be highly cherished and applauded.

We supplicate before Allah for more successes of AREA as well as all the participants of the workshop for more sincere service to our beloved motherland.

Thank you, 


\section{Terms of Reference for \\ Forestry Base-Line Survey in Afghanistan}

\section{Background:}

The environmental situation in Afghanistan is significantly deteriorating. Especially the situation of Afghanistan's forests leaves much to be desired. During the years of war, Afghanistan's forest resources have suffered tremendously under the lack of strong governmental institutions and uncontrolled felling. As a consequence, the forest resources of Afghanistan have reduced from 5 to $6 \%$ of the total covered area to around 1 to $2 \%$.

The process of rehabilitation, lack of alternative energy resources as well as the continued inadequate attention by the national and local authorities continue to further deter the forest resources of Afghanistan. Inadequate afforestation and reforestation programs, coupled with inadequate attention paid by the authorities and the aid community, will possibly lead to a complete eradication of Afghanistan's forest resources during the first decade of 2000. In view of this, it is extremely important that a strategy is developed to address the issue of deforestation at a national level to address ways of reducing deforestation and increasing reforestation and afforestation activities.

A workshop has been planned for end of July 1999 to address this specific need. The result of this workshop will be a comprehensive strategy document on ways of addressing the deforestation process, which is ongoing in Afghanistan.

As a preparation for this workshop, a base line survey will be carried out, which will clarify the status quo of Afghanistan's forest resources. The survey will further clarify the damage, which has been caused to these resources during the more than 20 years of war and destruction. The results of the survey shall be used as initial data for the planning and organizations of the workshop.

\section{Objectives:}

1. To record the status quo of Afghanistan's natural forest resources.

2. To identify and specify the level deforestation in the surveyed areas.

3. To identify the main and specific causes of deforestation for each individual forest area.

4. To identify main consumers of forest wood and specify the level of their consumption.

5. To identify the active involvement of the communities, authorities and the aid community in preventing deforestation and quantify their involvement.

6. To quantify the economical value of the forest resources as it is presently available and as it is consumed by the communities, authorities and individuals in form of trade, taxation, labor, transportation, etc. 


\section{Annex \#11}

7. To identify the possible level of consumption of wood at the domestic sphere, which directly affects the forest resources of Afghanistan.

8. To study the possible adaptability of introduction of alternatives to wood in the field of rehabilitation and energy consumption by the communities.

9. To identify possible intervention areas for rehabilitation and development of the natural forest resources of Afghanistan.

10. To study the level of awareness among the communities for the importance of forest resources and the level of destruction of these resources in various parts of Afghanistan.

11. To identify possible ways of introducing awareness creation activities among the Afghan communities in various locations.

\section{Survey Method:}

1. To collect all possible data about the forest resources of Afghanistan through UN, NGOs, government departments, Libraries, etc.

2. To prepare questionnaires, which address all objectives of the base line survey.

3. To analyze and utilize aerial and satellite pictures of the forest resources of Afghanistan, where possible, feasible and not significantly time and resource consuming.

4. To visit forest sites in Kunar, Nuristan, Laghman and Paktia as well as the central high lands, where wild almond forests grow.

5. To take samples of each locations and collect data about the past present and possible future (by 2010) status of the forest resources in the area.

6. To hold interviews with individuals as well as communities around the forest areas as well as communities outside the forest areas (rural and urban) and inquire about their behavior towards the forest resources.

7. To analyze the survey data and prepare a baseline survey report.

\section{Time Frame:}

The survey starts on May 11, 1999. The final report is submitted no later than July 25,1999 . The time spent in the field should not be less than 50 days. 
Annex \#12

\section{Terms of Reference for Workshop on Forestry Resources of Afghanistan}

\section{Background:}

The environmental situation in Afghanistan is significantly deteriorating. Especially the situation of Afghanistan's forests leaves much to be desired. During the years of war, Afghanistan's forest resources have suffered tremendously under the lack of strong governmental institutions and uncontrolled felling. As a consequence, the forest resources of Afghanistan have reduced from 5 to $6 \%$ of the total covered area to around 1 to $2 \%$.

The process of rehabilitation, lack of alternative energy resources as well as the continued inadequate attention by the national and local authorities continue to further deter the forest resources of Afghanistan. Inadequate afforestation and reforestation programs, coupled with inadequate attention paid by the authorities and the aid community, will possibly lead to a complete eradication of Afghanistan's forest resources during the first decade of 2000. In view of this, it is extremely important that a strategy is developed to address the issue of deforestation at a national level to address ways of reducing deforestation and increasing reforestation and afforestation activities.

A workshop has been planned for end of July 1999 to address this specific need. The result of this workshop will be a comprehensive strategy document on ways of addressing the deforestation process, which is ongoing in Afghanistan.

As a preparation for this workshop, a base line survey is being carried out, which will clarify the status quo of Afghanistan's forest resources. The survey will further clarify the damage, which has been caused to these resources during the more than 20 years of war and destruction. The results of the survey shall be used as initial data for the planning and organizations of the workshop.

\section{Objectives:}

The workshop will need to reach the following objectives:

1. To formulate a rehabilitation and development strategy for the forest resources of Afghanistan.

2. To identify problems and define the core problem with respect to the forest condition in Afghanistan. To prepare a problem tree, which contains the individual cause-effect relationships. 


\section{Annex \#12}

3. To formulate the objectives. Each objective must reflect one field of activity related to rehabilitation and development of the forest resources in Afghanistan. An objective tree must reflect the mean-end relationships of the individual objectives.

4. To quantify the objectives and describe reasonable time lines for individual indicators and if feasible.

5. To formulate strategies related to different objectives to be achieved within the context of the project purpose and the overall goal.

6. To formulate the assumptions related to individual objectives.

7. To define the OVI and the MoV pertaining to the objectives and the project purpose.

8. To workout at least two scenarios for two working conditions (a suitable and a less suitable conditions).

9. Prepare a detailed documentation of the workshop results.

\section{Workshop Method:}

1. The status quo of forest resources of Afghanistan must be very clear to the moderator. A copy of the forestry base-line survey will be provided to the moderator.

2. Workshop participants themselves shall formulate the problems, objectives, strategies and assumptions.

3. The moderator leads and facilitates the work of the team of planners, i.e. the participants.

4. The visualizing of all workshop procedures are carried out, utilizing cards on pinboards is used as a possible tool.

5. ZOPP is used as a planning tool.

6. To discuss the issues and record all proceedings in English language.

\section{Time Frame:}

The workshop shall start on July 28, 1999 and shall finish on July 31,1999 . The workshop times shall be between 0900 hours and 1630 hours. or. The final report of the survey team is submitted no later than July 20, 1999.

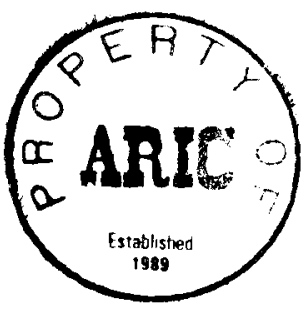




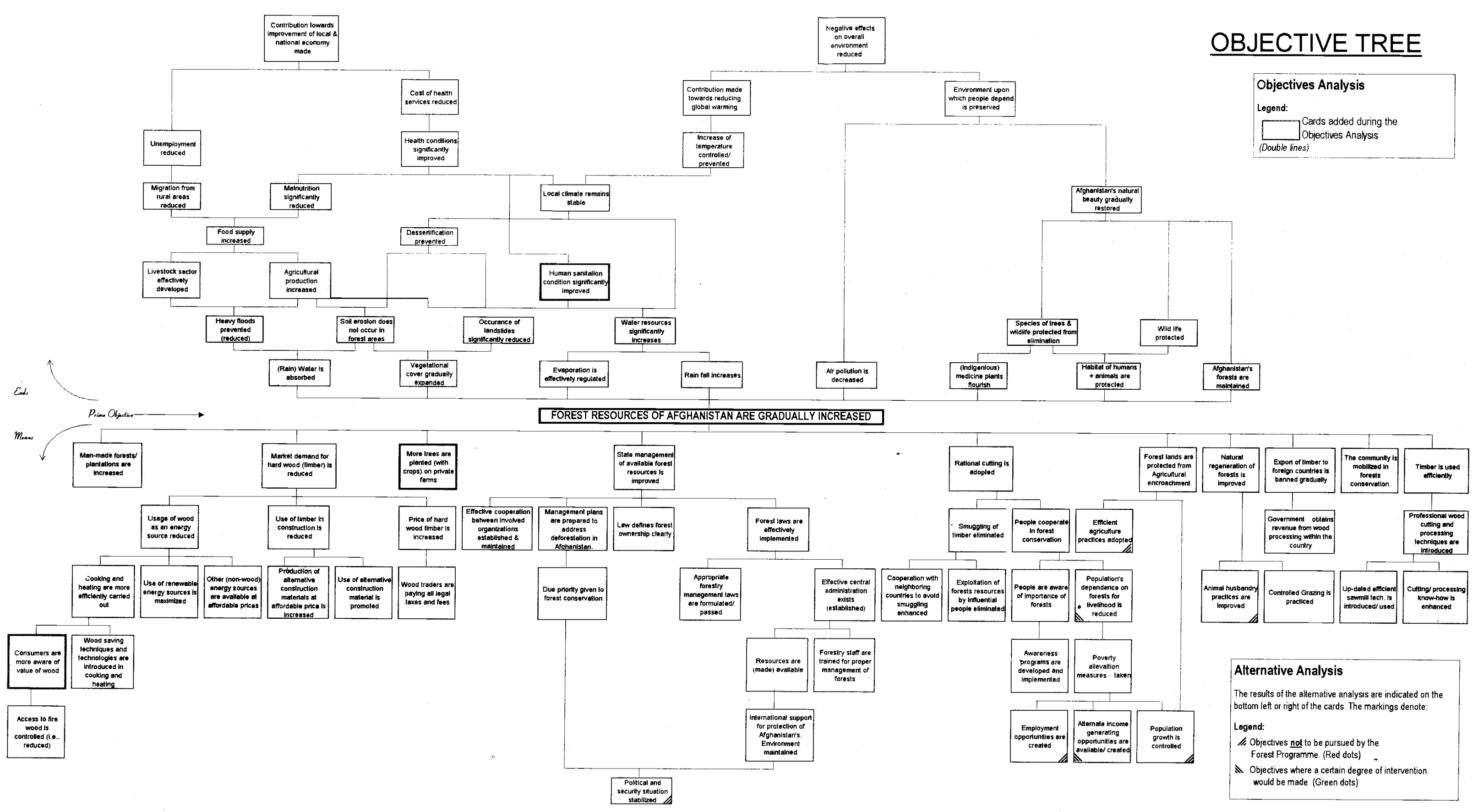




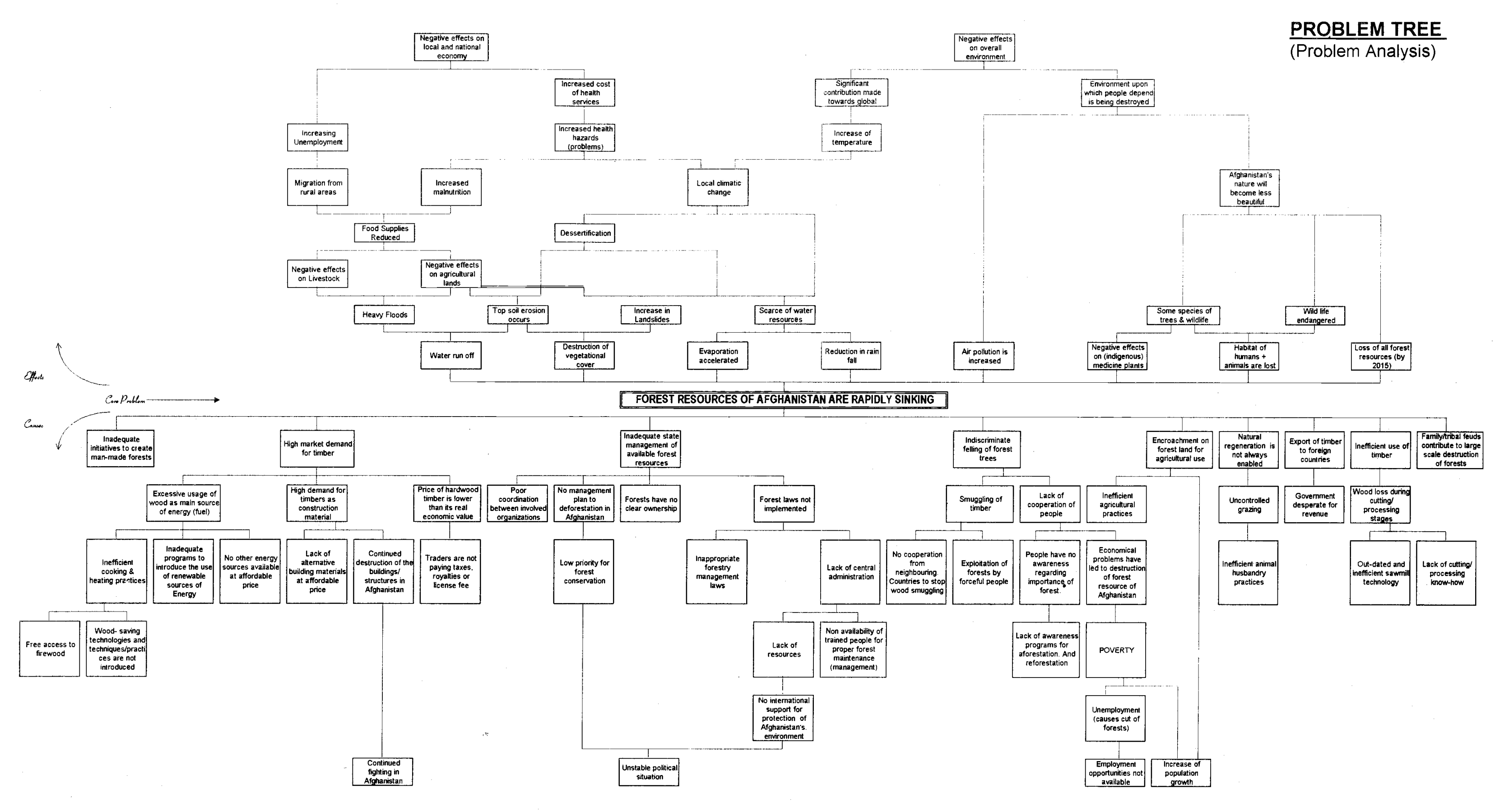


The last members of the Forest Family in Afghanistan have twisted their branches down onto their crumpled trunks. They are mourning for the bygones.

Distressed and panleked they are waiting for the cruel saws and axes to start operation at night.

"When shall it be my and your turn to be cut?" One whispers to the other. "Soon probably" choked with weep, the other answers.

" suffered and resisted coldest winters and hottest summer days and droughts for 25 years to produce fruit and shadow for ingratitude man and now he cuts me to pay my reward." Sighs the third.

A small self-grown innocemt sapling is afraid. Bending towards an old gigantic tree, it begs for shelter. And the giant tree extends one of its branches down to hug it. But a saw with sharklike teeth starts gnawing and soon the screeching branch falls down and smashes the sapling-

The flowers around the sapling all weep as they have lost a baby friend and they soon wither.

The hatchling that could climb only the sapling, is mourning now, rubbing its delicate small beak to the ground.

Only sensitive hearts can feel the sorrow and anguish of the grieved forest family.

To condole the mother-nature, ARFA believes that there are certain ways to apply ointment to the wounded hearts of the doleful surviving trees and bring an end to this massacrea Introduce alternatives to wood and promote the introduction of wood saving technologies. Use of alternative sources of energy such as wind, solar, hydro, biogas as well as alternative building materials are some solutions. AREA's wood saving, cooking, baking and heating technologies are other solutions.

Join hands with AREA and save Afghan forests in this moment of despair and grievance for every thing that lives and nurtures in Afghanistan. 